\title{
Leverage Expectations and Bond Credit Spreads
}

\author{
Mark J. Flannery, Stanislava (Stas) Nikolova, and Özde Öztekin*
}

\begin{abstract}
In an efficient market, spreads will reflect both the issuer's current risk and investors' expectations about how that risk might change over time. Collin-Dufresne and Goldstein (2001) show analytically that a firm's expected future leverage importantly influences the spread on its bonds. We use capital structure theory to construct proxies for investors' expectations about future leverage changes and find that these significantly affect bond yields, above and beyond the effect of contemporaneous leverage. Expectations under the trade-off, pecking order, and credit-rating theories of capital structure all receive empirical support, suggesting that investors view them as complementary when pricing corporate bonds.
\end{abstract}

\section{Introduction}

As credit-risk modeling has become more formalized, researchers have focused increasing attention on the information content and determinants of bond credit spreads. Financial theory indicates that a firm's default risk should be reflected in the value of its debt claims. Merton (1974) specifies that bond default risk depends upon the firm's asset volatility, its initial leverage, and the debt's term to maturity. Subsequent empirical studies have sought to explain credit spreads using firm leverage and a variety of proxies for asset volatility (e.g., Collin-Dufresne, Goldstein, and Martin (2001), Krishnan, Ritchken, and Thomson (2005), Avramov, Jostova, and Philipov (2007), and Campbell and

*Flannery, flannery@ufl.edu, Warrington College of Business Administration, University of Florida, PO Box 117168, Gainesville, FL 32611; Nikolova, nikolovas@ sec.gov, U.S. Securities and Exchange Commission, 100 F St NE, Washington, DC 20549; Öztekin, ozde.oztekin@fiu.edu, College of Business Administration, Florida International University, 11200 SW 8th St, Miami, FL 33199. We thank Hendrik Bessembinder (the editor), David Brown, Robert Goldstein (the referee), Jean Helwege, Jay Ritter, and seminar participants at American University, Florida State University, 2007 Financial Management Association European Meetings, 2007 European Financial Management Association Annual Meetings, Securities and Exchange Commission (SEC), and Commodity Futures Trading Commission (CFTC) for helpful comments and suggestions on prior drafts of this paper. The SEC disclaims responsibility for any private publication or statement of any SEC employee or Commissioner. This paper expresses the authors' views and does not necessarily reflect those of the Commission, the Commissioners, or other members of the staff. All remaining errors are our own. 
Taksler (2003)). This research indicates that most of a corporate bond's yield spread over Treasury is due to default risk, although taxes (Elton, Gruber, Agrawal, and Mann (2001)), liquidity (Longstaff, Mithal, and Neis (2005), Chen, Lesmond, and Wei (2007)), and systematic factors (Collin-Dufresne et al.) also seem to contribute.

The Merton (1974) model of credit spreads assumes that a firm's outstanding debt remains constant until maturity. Because expected asset returns are positive, this implies an expected decline in leverage over time, which generates relatively low credit spreads. Collin-Dufresne and Goldstein (CG) (2001) recognize that future changes in a firm's outstanding debt may substantially affect the riskiness of its multiperiod debt obligations. They model leverage as mean reverting and simulate credit spreads that conform more closely to those observed in the market. They conclude that "the appropriate credit spread for a corporate bond [reflects] . . . both the firm's current liability structure, and its right to alter this structure in the future" (p. 1930). In other words, bond prices should reflect not only current information about a firm's leverage but also investors' expectations about future leverage.

Two studies have attempted to calibrate the theoretical CG (2001) model to observed bond prices. First, Eom, Helwege, and Huang (2004) calibrate 5 theoretical models of credit spreads, including CG's, and they confirm that a firm's option to adjust its capital structure can have a 1st-order impact on bond credit spreads. However, in their implementation they adhere closely to the CG mean-reverting model of leverage and estimate only one relatively simple specification in which future leverage changes depend on current leverage and short-term risk-free rates. Second, Hui, Lo, and Huang (2006) expand the CG model by assuming that leverage mean-reverts to a time-varying rather than constant target, and they document that this assumption improves the model's accuracy. Taken together, these 2 studies suggest that leverage expectations should be an important determinant of bond credit spreads and that the model used to construct these expectations is consequential.

In this paper, we study a quarterly sample of 394 U.S. corporations' credit premia for the period 1986-1998. Following CG's (2001) intuition, we test whether proxies for future leverage affect observed bond spreads to a statistically and economically significant extent. Our analysis extends the previous research in an important way by estimating leverage expectations based on alternative theories of capital structure. This allows us to employ specific firm features to construct proxies for investors' expectations about the firm's future leverage, as opposed to the general mean-reversion models used by Eom et al. (2004) and Hui et al. (2006). We document that changes in leverage expectations do have a positive impact on credit-spread changes beyond the effect of contemporaneous leverage. Indeed, the impact of expected leverage is comparable to that of contemporaneous leverage, with a 1-standard-deviation increase in leverage expectations causing the issuer's bond credit spread to widen by nearly 100 basis points (bp). This finding is robust to alternative leverage definitions and alternative methods of forming expectations proxies. Our study contributes to the literature's understanding of what factors affect credit spreads and underscores the importance of investors' expectations in determining corporate bond prices. 
The rest of this paper is organized as follows: In Section II we develop our main hypotheses and describe the data we use to test them. Section III demonstrates that credit spreads reflect actual future leverage and that this effect is as powerful as the impact of contemporaneous leverage. Section IV describes how we form leverage expectations based on the trade-off, pecking order, and Kisgen (2006) credit-rating theories, and incorporates those expectations into regression models of nonfinancial firms' credit spreads. Section V verifies the robustness of our results. Section VI concludes.

\section{Bond Credit Spreads and Corporate Leverage: Theory}

In modeling a firm's bond spread we begin with a structural model of credit risk, derived from Black and Scholes' (1973) and Merton's (1974) application of contingent-claim analysis to equity and debt valuation. In this model, a firm defaults when its asset value falls below a default threshold, generally expressed in terms of its outstanding debt obligations. ${ }^{1}$ Credit spreads at time $t$ thus reflect the latest available information about the firm's default probability, which depends on current leverage and investors' expectations of future leverage. A linear version of this relationship is

$$
\mathrm{CS}_{i, j, t}=\alpha+\beta \cdot \mathrm{LEV}_{j, t}+\gamma \cdot \mathrm{E}_{t}\left(\mathrm{LEV}_{j, t+1}\right)+\boldsymbol{\theta} \cdot \mathbf{Z}_{\mathbf{t}}+\omega_{i, j, t},
$$

where

$\mathrm{CS}_{i, j, t}$ is the difference between the yield to maturity on bond $i$ of firm $j$ and the yield on a similar-maturity T-bond at the end of quarter $t$;

$\mathrm{LEV}_{j, t}$ is the ratio of debt to (debt + equity) of firm $j$ at the end of quarter $t$; and

$\mathbf{Z}_{\mathbf{t}}$ is a vector of control variables motivated by structural models such as Collin-Dufresne et al. (2001) and Duffie, Saita, and Wang (2007).

One naturally expects that $\beta>0$ : An increase in leverage raises the probability of default and hence the credit spread on outstanding bonds. We similarly expect $\gamma>0$ if investors use current information to form expectations about future leverage. $^{2}$

Some authors (e.g., Campbell and Taksler (2003)) estimate "levels" regressions of the form in equation (1), but this specification may yield spurious results if CS is not stationary (i.e., if it has a unit root). Indeed, this may be the main reason why most of the literature (Collin-Dufresne et al. (2001), Krishnan et al. (2005), and Avramov et al. (2007) among others) estimates equation (1) in the differences. In our data set, we fail to reject the hypothesis that a bond's CS series has a unit root for $80 \%$ of the bonds and for the overall panel. Although we retain

\footnotetext{
${ }^{1}$ The bond spreads generated by structural credit-risk models depend on risk-neutral parameters, while in our empirical analysis they are a function of true-probability parameters. We do not believe that this is a serious concern, since our study is not directly calibrating or testing the CG (2001) model. We merely use the theory developed in CG to motivate our hypotheses.

${ }^{2}$ Note that this relationship applies regardless of whether leverage is expected to change because of firm preferences or because a bond supply effect changes expected borrowing costs (as documented in Newman and Rierson (2004) or Dastidar (2008)).
} 
specification (1) as a robustness check, we employ a differences specification in most of our analysis:

$$
\Delta \mathrm{CS}_{i, j, t}=\beta \cdot \Delta \mathrm{LEV}_{j, t}+\gamma \cdot \Delta \mathrm{E}_{t}\left(\mathrm{LEV}_{j, t+1}\right)+\boldsymbol{\theta} \cdot \Delta \mathrm{Z}_{\mathbf{t}}+\varepsilon_{i, j, t}
$$

where $\varepsilon_{i, j, t}=\Delta \omega_{i, j, t}$.

First-differencing specification (1) has the added benefit of eliminating the effect of bond-specific features on the credit spread. It also permits us to form leverage expectations based on Kisgen's (2006) hypothesis (applicable to leverage changes but not leverage levels) that firms issue equity rather than debt when they are close to a rating change. We therefore present our results for the differences specification (2), although our conclusions about the statistical and economic significance of expected future leverage are also strongly supported by the levels specification (1).

Estimating specification (2) requires data on credit spreads, leverage expectations, and macroeconomic control variables. We obtain corporate bond data from the Warga-Lehman Brothers Fixed Income Database, which reports monthly price quotes for the major corporate and government debt issues traded in the United States. We limit our sample to coupon-paying bonds issued by U.S. industrial firms, and we eliminate bonds that are secured, those with a call or put feature, and those backed by specific assets (such as mortgages). As in Warga (1991) and Eom et al. (2004), we exclude bonds with less than 1 year to maturity because they are relatively illiquid. We also omit "matrix" prices, which Sarig and Warga (1989) find to be problematic. Finally, even though bond prices are available from Jan. 1973 to Mar. 1998, we begin our sample in Jan. 1986 because one of our control variables (VIX) is unavailable before that time. ${ }^{3}$

Each corporate bond's credit spread at the end of quarter $t\left(\mathrm{CS}_{i, j, t}\right)$ is defined as the difference between its yield and the corresponding constant-maturity Treasury yield, obtained from the Federal Reserve Board's H.15 releases. ${ }^{4}$ When there is no precise maturity match, we interpolate to obtain an appropriate Treasury yield. We eliminate from our sample observations for which $\mathrm{CS}_{i, j, t}$ is negative or greater than $10 \%$, as these are likely to be data entry errors or bonds in distress (for which a linear model like specification (2) is probably inappropriate). We define $\Delta \mathrm{CS}_{i, j, t}$ as the change in a bond's credit spread over the calendar quarter ending at $t$, and we winsorize this series at the 1 st and 99 th percentiles.

\footnotetext{
${ }^{3}$ The Warga-Lehman Brothers Fixed Income Database contains about 1.5 million monthly bond quotes for the period 1986-1998. After eliminating matrix prices and limiting our sample to corporate issuers we are left with a third of these quotes. We also exclude bonds with embedded options (about 300,000 data points) and bonds with credit-enhancing features (about 20,000). Eliminating financial firms and firms operating in regulated industries further reduces the number of observations by a third. After retaining only quarter-end observations for bonds whose issuers have quarterly Center for Research in Security Prices (CRSP) and Compustat data, we are left with about 17,000 bond-quarters. Constructing differences and eliminating quarterly changes where comparability (e.g., because of a merger, accounting change, etc.) is an issue further reduces our sample to about 14,000 bond-quarters.

${ }^{4}$ Our main results are essentially unchanged if we use the interest-rate swap curve instead of the Treasury yield curve to benchmark the corporate bond yields. However, using the swap rates reduces the number of observations because Bloomberg provides no swap rates before Nov. 1988.
} 
The quarterly Compustat file provides the data required to generate investor expectations about future leverage (see Appendix). We convert nominal accounting values to real 1983 values using the consumer price index and mitigate the effect of outliers by winsorizing the raw data and any resulting ratios at the 1st and 99 th percentiles.

Our initial analysis employs measures of both book leverage and market leverage. Book leverage is defined as

$$
\begin{aligned}
& \text { (3) } \mathrm{BLEV}=[(\text { Long-Term Debt }[51]+\text { Short-Term Debt[45]) } / \\
& (\text { Long-Term Debt[51] + Short-Term Debt[45] + Common Equity[59])], }
\end{aligned}
$$

where the numbers in brackets indicate the quarterly Compustat item numbers. Market leverage is defined as

$$
\text { MLEV }=\left[\frac{\text { Market Value of Debt }}{\text { Market Value of Debt }+ \text { Market Value of Equity }}\right] .
$$

We construct 2 alternative estimates of the market value of debt.

Bharath and Shumway (2008) estimate Compustat firms' debt market values using a Merton-type structural model of credit risk. The market value of risky debt is modeled as risk-free debt short a put option on the underlying market value of the firm's assets with a strike price equal to the face value of the firm's debt. Using observable firm characteristics, contingent-claim pricing implies a market value for the firm's equity and its debt. The leverage measure constructed from this estimated debt market value (MLEV1) can be computed for nearly all of our sample firms.

Our 2nd estimate of the market value of debt follows Sweeney, Warga, and Winters (1997), who extrapolate the firm's market value of debt from the subset of outstanding bonds with quoted prices (as opposed to matrix prices) in the Warga-Lehman Brothers Fixed Income Database. At the end of each quarter we form a portfolio of a firm's traded bonds (i.e., bonds with trader quotes available in the database). We then adjust the duration of this portfolio to match the duration of all the firm's bonds (i.e., those with trader quotes and those with matrix prices). The market value of this portfolio represents the price per bond, and we use it as a reasonable estimate of the market value of the firm's long-term debt (Compustat quarterly item 51). Short-term debt is assumed to trade at book value. ${ }^{5}$ We use this market value of debt estimate to construct our 2nd market leverage measure (MLEV2). It is available for fewer observations than MLEV1 because it relies on bond price availability, while MLEV1 does not.

Macroeconomic variables included to control for nonleverage-related effects on $\triangle \mathrm{CS}\left(\mathbf{Z}_{\mathbf{t}}\right.$ in equation (1)) are taken primarily from Collin-Dufresne et al. (2001) and Duffie et al. (2007): ${ }^{6}$

\footnotetext{
${ }^{5}$ We do not use any matrix prices in the calculation of the market value of debt because we are interested in capturing information about firm-specific events, and this can be masked by the use of matrix prices.

${ }^{6}$ Duffie et al. (2007) include 2 additional, firm-specific variables: $\mathrm{RET}_{j, t}=$ the $j$ th firm's stock return for the quarter ending at $t$; and $\mathrm{DD}_{j, t}=$ the $j$ th firm's distance to default (Bharath and
} 
$\mathrm{R}_{t}^{10}=$ the 10 -year, constant-maturity nominal $\mathrm{T}$-bond rate at the end of quarter $t$;

$\mathrm{SLOPE}_{t}=$ the difference between the 10- and 2-year Treasury yields at the end of quarter $t$;

VIX $_{t}=$ the implied volatility of the Standard \& Poor's (S\&P) 100 Index, calculated by the Chicago Board Options Exchange on the basis of historical data on the S\&P 100 Index options; ${ }^{7}$

$\mathrm{R}^{\mathrm{S} \& \mathrm{P}}=$ the return on the $\mathrm{S} \& \mathrm{P} 500$ Index for the quarter ending at $t$;

$\mathrm{JUMP}_{t}=$ the slope of the "smirk" of implied volatilities from options on

S\&P 500 Index futures, calculated as described in Collin-Dufresne et al. (2001), using option and futures prices obtained from the Chicago Mercantile Exchange;

CRPREM $_{t}=$ the difference between Moody's average yield on Baa- and Aaa-rated bonds, as a measure of market aversion to default risk. ${ }^{8}$

The average Treasury and corporate bond yields are obtained from the Federal Reserve Board's H.15 releases. VIX comes from the Chicago Board Options Exchange Web site (www.cboe.com/VIX), and $\mathrm{R}^{\mathrm{S} \& \mathrm{P}}$ comes from CRSP. Table 1 provides summary statistics for our final sample of 1,243 bonds issued by 394 U.S. industrial firms. The average number of quarterly quotes per bond is 18 , and the average number of bonds per firm is 3. ${ }^{9}$ The average credit spread is $1.06 \%$, and the average quarterly credit-spread change is $-0.01 \%$. The average book-valued (market-valued) leverage for our sample is $34 \%$ (33\% or $31 \%$ ), with a mean quarterly change of $-0.11 \%(-0.26 \%$ or $-0.27 \%)$.

\section{Credit Spreads and Realized Future Leverage}

We first test whether there is a connection between spread changes and actual future leverage innovations. Section IV then estimates equation (2) using alternative proxies for investors' expectations about future leverage.

Omitting future leverage changes from equation (2) results in the specification

$$
\Delta \mathrm{CS}_{i, j, t}=\beta \cdot \Delta \mathrm{LEV}_{j, t}+\boldsymbol{\theta} \cdot \Delta \mathrm{Z}_{\mathbf{t}}+\tilde{\varepsilon}_{i, j, t},
$$

Shumway (2008)) for the quarter ending at $t$. We are reluctant to include these variables in our base model because equity holders, like bondholders, will likely price expected-leverage changes. Adding any firm-specific equity information might therefore disguise the effects of leverage expectation on credit spreads. Nonetheless, including $\mathrm{RET}_{j, t}$ and $\mathrm{DD}_{j, t}$ in the set of explanatory variables does not alter our findings that leverage expectations significantly affect bond spreads.

${ }^{7}$ Strictly speaking, "VIX" refers to the implied volatility of the S\&P 500 Index options, but these data are unavailable before 1990 . We therefore use the implied volatility of the S\&P 100 Index options to measure market uncertainty throughout our sample period.

${ }^{8}$ Collin-Dufresne et al. (2001) do not include CRPREM in their base specification, but it enters the robustness portion of their analysis. They document that adding it to the set of explanatory variables more than doubles the model's adjusted $R^{2}$ and reduces by half the importance of the 1 st principal component in the regression residuals.

${ }^{9}$ Bonds do not appear to be concentrated by issuer. Of the 394 firms in our sample, only 73 have more than 4 bond issues, 58 have more than 5 bond issues, and 47 have more than 6 bond issues. Furthermore, several bond issues of the same firm are not always outstanding at the same time. 
TABLE 1

\section{Summary Statistics}

Table 1 presents summary statistics on our sample of 1,243 bonds issued by 394 unique industrial firms. The sample covers the period Jan. 1986-Mar. 1998 (when the bond-price data source ceased publishing).

\begin{tabular}{|c|c|c|c|c|c|c|}
\hline Variable & Definition & Mean & $\underline{\text { Std Dev }}$ & Median & Min & Max \\
\hline \multicolumn{7}{|c|}{ Panel A. Bond Characteristics } \\
\hline CS & $\begin{array}{l}\text { Credit spread measured as the difference } \\
\text { between the bond's yield and the yield on } \\
\text { a Treasury with equal maturity (\%) }\end{array}$ & 1.06 & 0.80 & 0.84 & 0.03 & 9.23 \\
\hline$\Delta \mathrm{CS}$ & $\begin{array}{l}\text { Change in credit spread between } \\
2 \text { consecutive quarter-ends (\%) }\end{array}$ & -0.01 & 0.24 & -0.01 & -0.89 & 1.01 \\
\hline Maturity & Bond maturity in years & 10.46 & 8.38 & 7.71 & 1.00 & 39.73 \\
\hline Duration & Bond duration in years & 6.05 & 2.97 & 5.75 & 0.95 & 13.35 \\
\hline Issue Amount & $\begin{array}{l}\text { Bond issue amount still outstanding } \\
\text { in \$thousands }\end{array}$ & 205,369 & 136,408 & 174,000 & 7,305 & $1,250,000$ \\
\hline Moody's Rating & $\begin{array}{l}\text { Moody's credit rating on } \\
\text { an ordinal scale with } 1=\text { Aaa }\end{array}$ & 7.12 & 2.69 & 7.00 & 1.00 & 18.00 \\
\hline \multicolumn{7}{|c|}{ Panel B. Leverage and Leverage Expectations } \\
\hline BLEV & $\begin{array}{l}\text { Book value of debt }([51]+[45]) / \\
\text { Book value of debt and equity }([51]+[45]+[59])\end{array}$ & 0.34 & 0.15 & 0.32 & 0.00 & 0.91 \\
\hline$\Delta \mathrm{BLEV}$ & Change in BLEV (\%) & -0.11 & 2.98 & -0.23 & -12.15 & 15.57 \\
\hline $\mathrm{BLEV}^{*}$ & Target BLEV & 0.27 & 0.06 & 0.28 & 0.07 & 0.46 \\
\hline$\Delta \mathrm{BLEV}^{*}$ & Change in target BLEV (\%) & -0.02 & 1.01 & -0.05 & -3.34 & 3.14 \\
\hline MLEV1 & $\begin{array}{l}\text { Market value of debt / } \\
\text { (Market value of debt + Market value of equity) } \\
\text { based on Bharath and Shumway (2008) }\end{array}$ & 0.33 & 0.19 & 0.30 & 0.01 & 0.85 \\
\hline$\Delta \mathrm{MLEV} 1$ & Change in MLEV1 (\%) & -0.26 & 3.87 & -0.36 & -29.14 & 31.05 \\
\hline MLEV1* & Target MLEV1 & 0.31 & 0.08 & 0.31 & 0.00 & 0.53 \\
\hline$\triangle \mathrm{MLEV} 1^{\star}$ & Change in target MLEV1 (\%) & -0.01 & 2.99 & -0.05 & -19.81 & 23.63 \\
\hline MLEV2 & $\begin{array}{l}\text { Market value of debt / } \\
\text { (Market value of debt + Market value of equity) } \\
\text { based on Sweeney et al. (1997) }\end{array}$ & 0.31 & 0.18 & 0.28 & 0.03 & 0.84 \\
\hline$\Delta \mathrm{MLEV} 2$ & Change in MLEV2 (\%) & -0.27 & 3.85 & -0.36 & -23.39 & 44.94 \\
\hline $\mathrm{MLEV}^{*}$ & Target MLEV2 & 0.28 & 0.07 & 0.28 & 0.00 & 0.49 \\
\hline$\triangle \mathrm{MLEV}^{*}$ & Change in target MLEV2 (\%) & -0.09 & 2.93 & -0.12 & -18.39 & 17.46 \\
\hline $\mathrm{E}_{t} \mathrm{FINDEFA}$ & Expected FINDEFA & 0.01 & 0.03 & 0.00 & -0.12 & 0.21 \\
\hline$\Delta \mathrm{E}_{t} \mathrm{FINDEFA}$ & Change in expected FINDEFA (\%) & -0.07 & 2.54 & -0.06 & -9.09 & 8.71 \\
\hline CRPOM & $\begin{array}{l}\text { An indicator variable equal to } 1 \text { if the firm's } \\
\text { credit rating was plus or minus, and } 0 \text { otherwise }\end{array}$ & 0.63 & 0.48 & 1.00 & 0.00 & 1.00 \\
\hline \multicolumn{7}{|c|}{ Panel C. Firm Characteristics } \\
\hline FINDEFA & Financing deficit / Total assets [44] & 0.01 & 0.05 & 0.00 & -0.18 & 0.30 \\
\hline EBIT_TA & $\begin{array}{l}\text { Earnings before interest and taxes }([8]+[22]+[6]) / \\
\text { Total assets }[44]\end{array}$ & 0.02 & 0.02 & 0.02 & -0.06 & 0.10 \\
\hline MB & $\begin{array}{l}\text { Book value of debt plus market value of equity } \\
([51]+[45]+[55]+[14] \times[61]) / \\
\text { Book value of total assets }[44]\end{array}$ & 1.23 & 0.61 & 1.08 & 0.32 & 4.42 \\
\hline DEP_TA & Depreciation [5] / Total assets [44] & 0.01 & 0.01 & 0.01 & 0.00 & 0.04 \\
\hline InTA & Log of total assets [44], measured in 1983 dollars & 22.44 & 1.14 & 22.51 & 18.48 & 24.73 \\
\hline FA_TA & Property, plant, and equipment [42] / Total assets [44] & 0.41 & 0.22 & 0.38 & 0.01 & 0.89 \\
\hline R\&D_TA & R\&D expenses [4] / Total assets [44] & 0.00 & 0.01 & 0.00 & 0.00 & 0.03 \\
\hline R\&D_DUM & $\begin{array}{l}\text { An indicator variable equal to } 1 \\
\text { if a firm did not report R\&D expenses, } \\
\text { and } 0 \text { otherwise }\end{array}$ & 0.40 & 0.49 & 0.00 & 0.00 & 1.00 \\
\hline RATED & $\begin{array}{l}\text { An indicator variable equal to } 1 \\
\text { if the firm has a public debt rating in Compustat, } \\
\text { and } 0 \text { otherwise }\end{array}$ & 0.99 & 0.12 & 1.00 & 0.00 & 1.00 \\
\hline IND_MED & $\begin{array}{l}\text { Prior quarter's median leverage ratio } \\
\text { for the firm's industry. Industries defined } \\
\text { according to Fama and French (1997) }\end{array}$ & 0.20 & 0.06 & 0.20 & 0.05 & 0.59 \\
\hline MVE $(\$ M)$ & Market value of equity & 12,034 & 17,131 & 5,098 & 23 & 85,086 \\
\hline
\end{tabular}




\begin{tabular}{|c|c|c|c|c|c|c|}
\hline \multicolumn{7}{|c|}{$\begin{array}{l}\text { TABLE } 1 \text { (continued) } \\
\text { Summary Statistics }\end{array}$} \\
\hline Variable & Definition & Mean & $\underline{\text { Std Dev }}$ & Median & Min & Max \\
\hline \multicolumn{7}{|c|}{ Panel D. Macro Variables Measuring Bond Market Conditions } \\
\hline$\Delta \mathrm{R}^{10}$ & $\begin{array}{l}\text { Change in the spot rate measured as } \\
\text { the 10-year Treasury yield }\end{array}$ & -0.04 & 0.52 & -0.02 & -1.89 & 1.36 \\
\hline$\triangle \mathrm{SLOPE}$ & $\begin{array}{l}\text { Change in the slope of the yield curve measured } \\
\text { as the difference between } \\
\text { the 10- and 2-year Treasury yields }\end{array}$ & -0.05 & 0.27 & -0.06 & -0.85 & 0.68 \\
\hline$R^{S \& P}$ & Quarterly S\&P 500 Index return & 0.03 & 0.05 & 0.04 & -0.30 & 0.20 \\
\hline$\Delta \mathrm{VIX}$ & Change in the implied volatility of the S\&P 500 Index & 0.29 & 3.83 & 0.02 & -25.86 & 44.96 \\
\hline$\triangle J U M P$ & $\begin{array}{l}\text { Change in the slope of the "smirk" of implied } \\
\text { volatilities of options on S\&P } 500 \text { Index futures }\end{array}$ & 0.02 & 1.21 & 0.12 & -5.89 & 6.78 \\
\hline$\triangle$ CRPREM & $\begin{array}{l}\text { Change in the credit-risk premium measured as } \\
\text { the difference between the yields on Aaa- and } \\
\text { Baa-rated bonds }\end{array}$ & -0.01 & 0.10 & 0.00 & -0.33 & 0.32 \\
\hline
\end{tabular}

where $\tilde{\varepsilon}_{i, j, t}=\gamma \cdot \Delta \mathrm{E}_{t}\left(\mathrm{LEV}_{j, t+1}\right)+\varepsilon_{i, j, t}$. The coefficient on $\Delta \mathrm{E}_{t}\left(\mathrm{LEV}_{j, t+1}\right)$ might be different from 0 for either of two reasons. First, our hypothesis that a change in expected future leverage affects contemporaneous credit spreads implies that $\gamma>0$. If investors' expectations are rational, a positive residual in specification (5) should tend to be followed by higher leverage, and a negative residual should be followed by lower leverage. An alternative hypothesis reverses this proposed causation: A reduction (increase) in credit spreads encourages the firm to seek more (less) debt financing because debt has become relatively cheap (expensive). In this case, $\gamma$ should be negative, so positive (negative) residuals should be followed by lower (higher) leverage.

Table 2 presents ordinary least squares (OLS) estimates of equation (5) for book leverage (BLEV) and both market leverage measures (MLEV1 and MLEV2). All 3 contemporaneous leverage measures significantly affect a firm's credit spread. The signs on the control variables' coefficients are consistent with theory. We therefore feel comfortable using the residuals from these estimations to separate observations into one group with positive residuals and another group with negative residuals. Table 3 examines how these residuals are related to subsequent leverage changes. ${ }^{10}$

Panel A of Table 3 tests whether subsequent leverage changes are the same for firms with positive versus negative residuals from equation (5). We reject this hypothesis for leverage changes up to 4 quarters ahead, based on both a $t$-test of mean leverage changes and a nonparametric (Wilcoxon) test of median changes. ${ }^{11}$ Positive regression residuals are followed by significantly higher

\footnotetext{
${ }^{10} \mathrm{An}$ alternative way to evaluate the effect of future leverage is to add future values of leverage as additional explanatory variables in equation (5). See column 1 of Table 4.

${ }^{11}$ After rejecting the hypothesis that the 2 residual groups have equal variances, we use an appropriate $t$-test.
} 
TABLE 2

\section{Credit-Spread Changes and Contemporaneous Leverage Changes}

In Table 2, results are from an OLS estimation of the following model on the sample of 1,243 bonds over the 1986-1998 period:

$$
\Delta \mathrm{CS}_{i, j, t}=\beta \cdot \Delta \mathrm{LEV}_{j, t}+\boldsymbol{\theta} \cdot \boldsymbol{\Delta} \mathbf{Z}_{\mathbf{t}}+\tilde{\varepsilon}_{i, j, t}
$$

Here, $\Delta \mathrm{CS}=$ change in bond credit spreads; $\Delta \mathrm{LEV}=$ change in book (BLEV) or market (MLEV1, MLEV2) leverage ratio; $\Delta \mathbf{Z}$ includes the following structural-model motivated variables: $\Delta \mathrm{R}=$ change in the spot rate measured by the 10-year Treasury yield: $\triangle$ SLOPE $=$ change in the slope of the yield curve measured as the difference between 10- and 2-year Treasury yields; $\Delta \mathrm{VIX}=$ change in the implied volatility on the S\&P 500 Index; S\&P = quarterly S\&P 500 Index return; $\Delta J U M P=$ change in the slope of the "smirk" of implied volatilities of options on S\&P 500 Index futures; and $\Delta$ CRPREM $=$ change in the spread between the yield on Aaa- and Baa-rated bonds. Changes are measured over consecutive quarters. Robust standard errors are reported in parentheses. Statistical significance at the $1 \%, 5 \%$, and $10 \%$ levels is indicated by ${ }^{\star \star \star},{ }^{* *}$, and ${ }^{*}$, respectively.

\begin{tabular}{|c|c|c|c|}
\hline & \multicolumn{3}{|c|}{ Leverage Measure } \\
\hline & BLEV & MLEV1 & MLEV2 \\
\hline$\Delta \mathrm{LEV}_{t}$ & $\begin{array}{l}0.386^{\star \star \star} \\
(0.068)\end{array}$ & $\begin{array}{l}1.017^{\star \star \star} \\
(0.075)\end{array}$ & $\begin{array}{l}0.846^{\star \star \star} \\
(0.084)\end{array}$ \\
\hline$\Delta \mathrm{R}_{t}^{10}$ & $\begin{array}{l}-0.098^{\star \star \star} \\
(0.004)\end{array}$ & $\begin{array}{l}-0.096^{\star \star \star} \\
(0.004)\end{array}$ & $\begin{array}{l}-0.091^{\star * *} \\
(0.005)\end{array}$ \\
\hline$\left(\Delta \mathrm{R}_{t}^{10}\right)^{2}$ & $\begin{array}{l}0.096^{\star \star \star} \\
(0.006)\end{array}$ & $\begin{array}{l}0.099^{\star \star \star} \\
(0.007)\end{array}$ & $\begin{array}{l}0.112^{\star \star \star} \\
(0.008)\end{array}$ \\
\hline$\Delta \mathrm{SLOPE}_{t}$ & $\begin{array}{l}-0.117^{\star \star \star} \\
(0.008)\end{array}$ & $\begin{array}{l}-0.115^{\star \star \star} \\
(0.008)\end{array}$ & $\begin{array}{l}-0.114^{\star * *} \\
(0.009)\end{array}$ \\
\hline$\Delta \mathrm{VIX}_{t}$ & $\begin{array}{l}0.006^{\star \star \star} \\
(0.001)\end{array}$ & $\begin{array}{l}0.005^{\star \star \star} \\
(0.001)\end{array}$ & $\begin{array}{l}0.005^{\star \star \star} \\
(0.001)\end{array}$ \\
\hline $\mathrm{R}_{t}^{S \& \mathrm{P}}$ & $\begin{array}{c}-0.077 \\
(0.062)\end{array}$ & $\begin{array}{c}0.050 \\
(0.059)\end{array}$ & $\begin{array}{c}-0.050 \\
(0.064)\end{array}$ \\
\hline$\Delta \mathrm{JUMP}_{t}$ & $\begin{array}{l}0.029^{\star \star \star} \\
(0.002)\end{array}$ & $\begin{array}{l}0.026^{\star \star \star} \\
(0.002)\end{array}$ & $\begin{array}{l}0.025^{\star \star \star} \\
(0.002)\end{array}$ \\
\hline$\Delta$ CRPREM $_{t}$ & $\begin{array}{l}0.389^{\star \star \star} \\
(0.020)\end{array}$ & $\begin{array}{l}0.369^{\star \star \star} \\
(0.027)\end{array}$ & $\begin{array}{l}0.285^{\star \star *} \\
(0.031)\end{array}$ \\
\hline Intercept & $\begin{array}{l}-0.048^{\star \star \star} \\
(0.003)\end{array}$ & $\begin{array}{l}-0.046^{\star \star \star} \\
(0.003)\end{array}$ & $\begin{array}{l}-0.053^{\star \star \star} \\
(0.003)\end{array}$ \\
\hline $\begin{array}{l}\text { No. of obs. } \\
\text { Adj. } R^{2}\end{array}$ & $\begin{array}{c}13,764 \\
0.11\end{array}$ & $\begin{array}{c}13,693 \\
0.13\end{array}$ & $\begin{array}{c}10,122 \\
0.12\end{array}$ \\
\hline
\end{tabular}

leverage changes, and vice versa. These findings are robust to the inclusion of bond or firm fixed effects in regression (5) (not tabulated). The significantly positive relationship between these residuals and subsequent leverage changes implies that leverage expectations are the dominant influence on a firm's credit spread. In other words, credit spreads reflect (rather than cause) future leverage changes.

We further examine the residuals from regression (5) to determine which specific components of future leverage are reflected in current bond prices. We rewrite the general definition of market-valued leverage (4) as

$$
\mathrm{MLEV}=\left[\frac{\mathrm{D} p_{d}}{\mathrm{D} p_{d}+\mathrm{S} p_{s}}\right]
$$

where

$\mathrm{D}$ is the nominal value of outstanding debt,

$\mathrm{S}$ is the number of outstanding shares,

$p_{d}$ is the market price of a $\$ 1$ bond, and

$p_{s}$ is the market price of a share of stock. 


\section{TABLE 3}

\section{Credit-Spread Changes and Realized Future Leverage Changes}

Panel A of Table 3 presents tests that evaluate the hypothesis that firms with positive residuals from the OLS estimation in Table 2 experience larger $k$-period-ahead increases in leverage than do firms with negative residuals. Here, $\Delta L E V_{i,[t, t+k]}^{N e g}$ and $\Delta \mathrm{LEV}_{i,[t, t+k]}^{\mathrm{Pos}}$ are the $k$-quarter-ahead changes in leverage for firms with negative and positive residuals, respectively. Panel B presents test statistics for the hypotheses that subsequent changes in each of the 4 components of leverage changes are the same for firms with positive versus negative residuals from the OLS estimation of equation (5). Here, $\Delta_{1}$ LEV and $\Delta_{3}$ LEV are the leverage changes through debt issuances/repayments and equity issuances/repurchases, respectively; $\Delta_{2}$ LEV and $\Delta_{4}$ LEV are the leverage changes through debt price changes and equity price changes, respectively. The $t$-tests with the assumption of unequal variances test whether the means of the 2 residual groups are equal (against the alternative that the difference between them is strictly positive), and nonparametric Wilcoxon median tests assess whether the medians of the 2 residual groups are equal (against the alternative that they are different). Statistical significance at the $1 \%, 5 \%$, and $10 \%$ levels is indicated by ${ }^{* * *},{ }^{\star *}$, and ${ }^{*}$, respectively.

Panel A. Future Leverage Changes

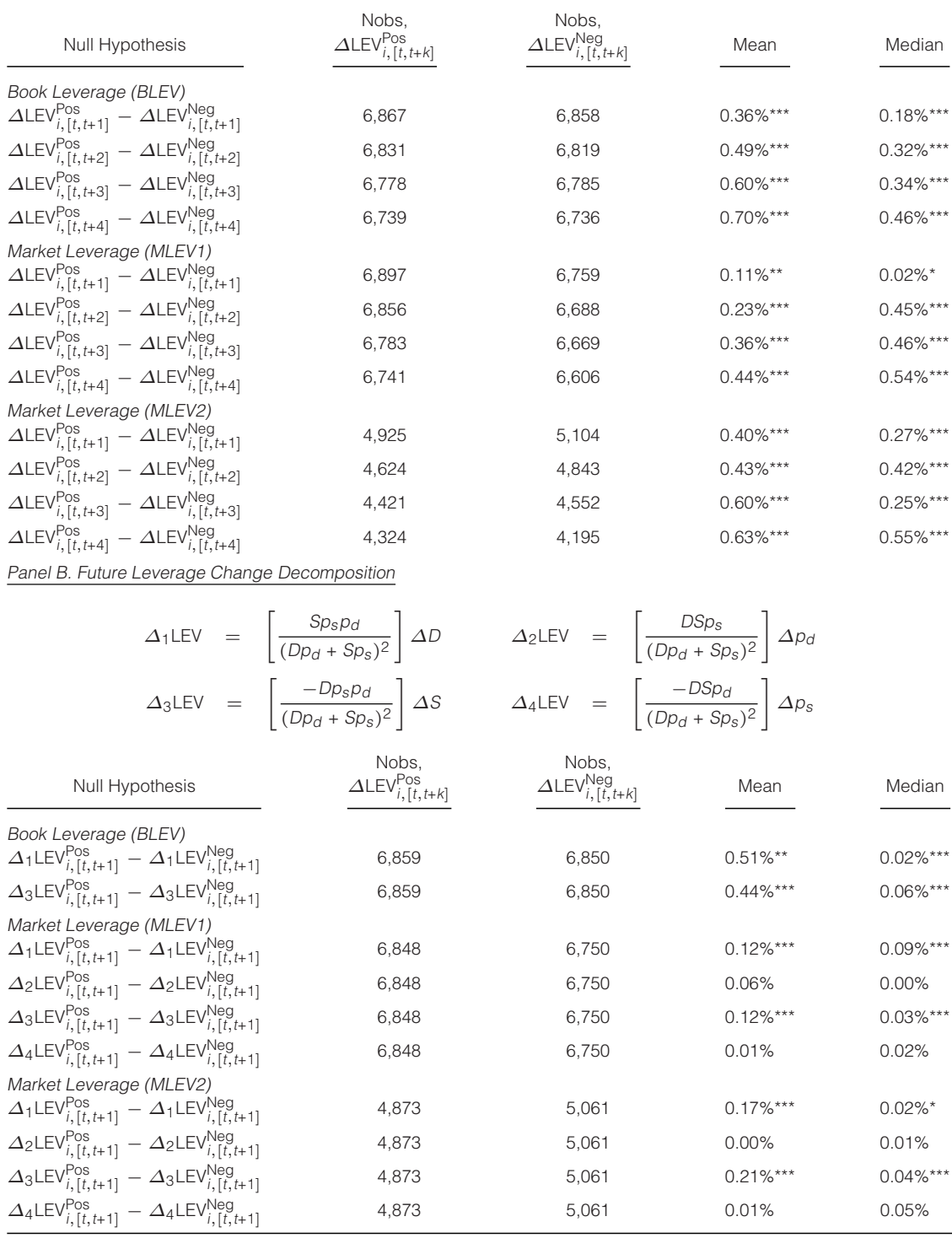


Leverage is affected by a change in the quantity or price of either debt or equity outstanding. ${ }^{12}$ That is,

$$
\begin{aligned}
\Delta \mathrm{MLEV} & =\left[\frac{\mathrm{S} p_{s} p_{d} \Delta \mathrm{D}+\mathrm{S} p_{s} \mathrm{D} \Delta p_{d}-\mathrm{D} p_{s} p_{d} \Delta \mathrm{S}-\mathrm{D} p_{d} \mathrm{~S} \Delta p_{s}}{\left(\mathrm{D} p_{d}+\mathrm{S} p_{s}\right)^{2}}\right] \\
& \equiv \Delta 1+\Delta 2+\Delta 3+\Delta 4,
\end{aligned}
$$

where

$\Delta 1=$ the change in leverage due to a change in outstanding debt, $\Delta 2=$ the change in leverage due to a change in the price of debt, $\Delta 3=$ the change in leverage due to a change in outstanding shares, and $\Delta 4=$ the change in leverage due to a change in share price. ${ }^{13}$

Note that for quarterly changes in book leverage (BLEV) $\Delta 2=\Delta 4=0$.

Since market efficiency implies that investors should be unable to forecast bond or share price movements, we do not expect bond yield spreads to be affected by price-driven changes in future leverage. Rather, the future leverage changes anticipated by investors should reflect only $\Delta 1$ and $\Delta 3$, the components under management's direct control. Consistent with the hypothesis of market efficiency, Panel B of Table 3 indicates that the residuals from equation (5) predict only the components of leverage changes due to changes in bonds or shares issued. Regardless of the leverage measure used (market vs. book-valued), both a $t$-test of means and a nonparametric (Wilcoxon) test of medians reject the hypothesis that $\Delta 1$ and $\Delta 3$ are the same following firm-quarter observations with positive versus negative residuals from equation (5). By contrast, the mean and median leverage changes due to price fluctuations, $\Delta 2$ and $\Delta 4$, never differ between the 2 groups. ${ }^{14}$ These findings suggest that book leverage might be a more appropriate basis for constructing measures of leverage expectations. We therefore present most of our remaining analysis using book-valued leverage ratios, although results are consistent when using MLEV1 and MLEV2 (not tabulated).

\section{Credit Spreads and Expected Future Leverage}

Given that subsequent leverage changes affect credit spreads, one naturally wonders how investors form expectations about these leverage changes. Fortunately, the corporate finance literature provides several theories of leverage choice. We construct estimates of investors' future leverage expectations under the tradeoff, pecking order, and credit-ratings-based (Kisgen (2006)) hypotheses of capital structure. These estimates are explained and derived in the Appendix, and their summary statistics are included in Table 1 . Briefly, the 3 expected future leverage estimates are

\footnotetext{
${ }^{12}$ We thank the referee for pointing out this distinction among the components of leverage change.

${ }^{13}$ The change in the value of equity as a result of market-price changes is calculated as the difference between the market-value change and the book-value change in common stock. The change in the value of debt due to changes in yields is similarly defined.

${ }^{14}$ This pattern occurs up to 3 quarters into the future, although only the 1st quarter's results are tabulated in Panel B of Table 3.
} 
$\Delta \mathrm{E}_{t}\left(\mathrm{BLEV}_{j, t+1}^{*}\right)=$ the change in firm $j$ 's expected target leverage during the quarter ending at $t+1$, conditional on information available at the end of quarter $t$. The target leverage ratio $\left(\mathrm{BLEV}^{*}\right)$ is computed from a partial adjustment model estimated via generalized method of moments (GMM), as described in the Appendix. Under the trade-off theory, firms currently operating below their leverage target would prefer to issue debt rather than equity in an attempt to reach their optimal leverage level.

$\Delta \mathrm{E}_{t}\left(\right.$ FINDEFA $\left._{j, t+1}\right)=$ the change in firm $j$ 's expected financing deficit in quarter $t+1$, conditional on information available at the end of quarter $t$. The pecking order hypothesis predicts that firms generally prefer to issue debt rather than equity when they need to raise external capital. Therefore, a positive expected financing deficit implies an expected increase in leverage, and vice versa.

$\mathrm{CRPOM}_{j, t}=1$ when firm $j$ 's credit rating in quarter $t$ includes a plus or minus, and 0 otherwise. For example, CRPOM $=1$ for firms rated A+ or A-, but not A. Kisgen (2006) argues that firms with "minus" ratings wish to avoid falling to the next lower letter category, and firms with "plus" ratings generally wish to raise themselves to the next higher letter category. He shows that firms with a plus or minus credit rating are less likely to issue debt (relative to equity) for at least a year.

These theories of leverage choice are not mutually exclusive. For instance, $\mathrm{E}_{t}\left(\mathrm{BLEV}_{j, t+1}^{*}\right)$ might be describing investors' expectations about a firm's longterm leverage target, while $\Delta \mathrm{E}_{t}\left(\right.$ FINDEFA $\left._{j, t+1}\right)$ might imply a temporary leverage change. This is why we examine the effect of the above expected-leverage proxies on bond credit spreads both individually and jointly.

Table 4 presents results from adding 1 or more leverage-expectation proxies into the base regression (2). Column 1 uses 4 subsequent, actual leverage changes as a "perfect foresight" set of expectations. Columns 2-5 report results based on 1 or more of our 3 theory-based expectations. As predicted by theory and confirmed by previous empirical studies, contemporaneous leverage is positively related to credit spreads, and this effect appears to be economically large. A 1-standard-deviation change $(2.98 \%)$ in book leverage $(\triangle \mathrm{BLEV})$ causes a 78-137 bp change in bond credit spreads across the 5 specifications. This is a large economic effect, since the standard deviation of spreads is $80 \mathrm{bp}$ (Table 1). Beyond the impact of contemporaneous leverage on credit spreads, 3 of 4 realized future leverage changes in column 1 carry significantly positive coefficients, consistent with the results in Table 3.

The expected-leverage proxies also carry statistically and economically significant coefficients. In column 2 of Table 4, the effect of target leverage appears comparable to that of contemporaneous leverage: A 1-standard-deviation change $(1.01 \%)$ in target leverage $\left(\mathrm{BLEV}^{*}\right)$ causes a 100 -bp change in bond spreads. Column 3 presents similar results when investor expectations are represented by 
TABLE 4

Credit-Spread Changes and Expected-Leverage Changes

These are the results from an OLS estimation of the following model on the sample of 1,243 bonds from 1986 to 1998

$$
\Delta \mathrm{CS}_{i, j, t}=\beta \cdot \Delta \mathrm{LEV}_{j, t}+\gamma \cdot \Delta \mathrm{E}_{t}\left(\operatorname{LEV}_{j, t+1}\right)+\boldsymbol{\theta} \cdot \Delta \mathbf{Z}_{\mathbf{t}}+\varepsilon_{i, j, t} .
$$

Here, $\Delta \mathrm{CS}=$ change in bond credit spreads; $\Delta \mathrm{LEV}=$ change in the book leverage ratio, $\mathrm{BLEV} ; \Delta \mathrm{E}(\mathrm{LEV})$ is alternatively proxied by $\Delta \mathrm{E}\left(\mathrm{BLEV}^{\star}\right) ; \Delta \mathrm{E}(\mathrm{FINDEFA})$, and $\mathrm{CRPOM} ; \Delta \mathrm{E}\left(\mathrm{BLEV}^{\star}\right)=$ change in target leverage ratio; target BLEV is the fitted value from a Blundell-Bond (1998) GMM estimation of equation (A-3); $\Delta \mathrm{E}(\mathrm{FINDEFA})=\mathrm{change}$ in expected financing deficit scaled by total assets; expected FINDEFA is the fitted value from an OLS estimation of equation (A-7) (specification (1) in Table A2); $\mathrm{CRPOM}=1$ for plus/minus credit ratings, and 0 otherwise; and $\Delta_{k} \mathrm{LEV} t$ is the $k$-quarter-ahead change in leverage. Estimated coefficients on the macroeconomic control variables $\left(\mathbf{Z}_{\mathbf{t}}\right)$ closely resemble those in Table 2 and are omitted here to save space. Robust standard errors are reported in parentheses. Our main results are not changed by using boot-strapped standard errors or standard errors adjusted for bond or firm clustering. Statistical significance at the $1 \%, 5 \%$, and $10 \%$ levels is indicated by ${ }^{\star \star \star}$, ${ }^{\star *}$, and ${ }^{*}$, respectively. $F$ is the $F$-statistic testing the hypothesis that the coefficients on all $3 \Delta \mathrm{E}(\mathrm{LEV})$ proxies are jointly 0 ( $\mathrm{df}=3$, [nobs - ncoeff]).

\begin{tabular}{|c|c|c|c|c|c|}
\hline & 1 & 2 & 3 & 4 & 5 \\
\hline$\Delta \mathrm{BLEV}_{t}$ & 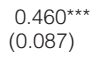 & $\begin{array}{l}0.336^{\star \star \star} \\
(0.086)\end{array}$ & $\begin{array}{l}0.308^{\star \star \star} \\
(0.089)\end{array}$ & $\begin{array}{l}0.383^{\star * *} \\
(0.083)\end{array}$ & $\begin{array}{l}0.262^{\star \star \star} \\
(0.090)\end{array}$ \\
\hline$\Delta \mathrm{E}_{t}\left(\mathrm{BLEV}_{t+1}^{*}\right)$ & & $\begin{array}{l}0.990^{* * *} \\
(0.222)\end{array}$ & & & $\begin{array}{l}0.994^{\star * *} \\
(0.222)\end{array}$ \\
\hline$\Delta \mathrm{E}_{t}\left(\mathrm{FINDEFA}_{t+1}\right)$ & & & $\begin{array}{l}0.369^{\star * *} \\
(0.098)\end{array}$ & & $\begin{array}{l}0.389^{* * *} \\
(0.098)\end{array}$ \\
\hline $\mathrm{CRPOM}_{t}$ & & & & $\begin{array}{l}-0.018^{\star \star \star} \\
(0.004)\end{array}$ & $\begin{array}{c}-0.017^{\star \star \star} \\
(0.004)\end{array}$ \\
\hline$\Delta_{1} \mathrm{LEV}_{t}$ & $\begin{array}{l}0.595^{\star \star \star} \\
(0.079)\end{array}$ & & & & \\
\hline$\Delta_{2} \mathrm{LEV}_{t}$ & $\begin{array}{l}0.172^{\star \star} \\
(0.082)\end{array}$ & & & & \\
\hline$\Delta_{3}$ LEV $_{t}$ & $\begin{array}{l}0.327^{\star \star \star} \\
(0.085)\end{array}$ & & & & \\
\hline$\Delta_{4} \mathrm{LEV}_{t}$ & $\begin{array}{c}0.070 \\
(0.087)\end{array}$ & & & & \\
\hline $\begin{array}{l}\text { No. of obs. } \\
\text { Adj. } R^{2} \\
\text { F }\end{array}$ & $\begin{array}{c}13,461 \\
0.12\end{array}$ & $\begin{array}{c}13,434 \\
0.11\end{array}$ & $\begin{array}{c}13,764 \\
0.11\end{array}$ & $\begin{array}{c}13,747 \\
0.11\end{array}$ & $\begin{array}{c}13,418 \\
0.11 \\
18.19^{\star \star \star}\end{array}$ \\
\hline
\end{tabular}

the "pecking order" proxy. The estimated coefficient on expected financing deficit is highly significant and indicates a large economic impact: The spread changes $94 \mathrm{bp}$ for a 1 -standard-deviation change in $\Delta \mathrm{E}_{t}\left(\mathrm{FINDEFA}_{j, t+1}\right)$. Kisgen's (2006) CRPOM indicator also carries a significant coefficient (in column 4), with the expected negative sign: Firms with "plus or minus" credit ratings are considered less likely to issue debt in the near future. When all 3 proxy variables are included in the same regressions (column 5 of Table 4), their estimated coefficients remain significant and close to their values in the preceding 3 columns. Thus, each proxy adds some information to the other two. The same conclusions hold for marketvalued leverage (results not tabulated).

Since all proxies carry a significant coefficient of the expected sign, Table 4 provides little basis for separating one theory of leverage determination from another. However, the capital structure literature argues that different theories may describe different types of firms. Under the trade-off theory of capital structure, firms compare the bankruptcy costs of debt to its tax-shield benefits in selecting an optimal leverage ratio. Therefore, leverage targets might be more informative about future leverage for firms more likely to incur these costs or more likely to value these benefits. According to the pecking order theory, financing 
decisions are guided by the existence of asymmetric information costs, which are likely to be higher for equity issuances than for debt issuances. This implies that for firms facing low asymmetric information costs, pecking order considerations might be less relevant in forming expectations about future leverage changes. Finally, Lemmon and Zender (2010) argue that firms subject to high default risk might be limited in their ability to borrow funds despite their preference for debt over equity financing. These debt-capacity-constrained firms might deviate from the predictions of the pecking order theory, making their financing deficit a less relevant basis for predicting future leverage.

We investigate whether firm characteristics proxying for bankruptcy costs, tax-shield benefits, asymmetric information, and debt-capacity constraints affect the sensitivity of bond credit spreads to the 3 proxies for expected future leverage. Table 5 reports the results from reestimating the main model (2) for subsets of firms grouped according to their leverage, size, profitability, and credit rating. ${ }^{15}$ The estimations use book leverage (BLEV defined in equation (3)) and include all the control variables from regression (2). To save space, we do not report the estimated coefficients on these control variables.

The 1st noteworthy point in Table 5 is that the leverage proxies significantly affect contemporaneous credit spreads for nearly all subsamples. For only 1 of the 11 subsamples (the largest size tercile, column 6) do we fail to reject the hypothesis that our 3 leverage proxies significantly affect credit spreads. In 8 subsamples we reject this joint hypothesis at the $1 \%$ confidence level, while in the other two we reject it at the 5\% and 10\% levels. In contrast, 4 of the 11 subsamples yield insignificant coefficients on contemporaneous leverage, though all four have the correct sign. This confirms that expected future leverage is at least as important as contemporaneous leverage in determining bond spreads.

The individual proxies tend to be significant in Table 5 for the types of firms for which they are expected to be most relevant. The "trade-off" proxy for future leverage carries a significant coefficient in 9 subsamples, and the relative size of the coefficients seems intuitively reasonable. For example, the coefficient for high-leverage firms exceeds the coefficient for low leverage, low profitability exceeds high profitability, and junk (far) exceeds investment grade. The "pecking order" proxy is significant in 6 of the 11 subsamples, frequently when informational asymmetries might be higher (small and medium-size firms, and low-profitability firms). The CRPOM proxy is significantly negative in 7 subsamples. We observe insignificant CRPOM coefficients for the high-leverage, large, and high-profitability groups. Surprisingly, the junk bond subsample has an insignificant coefficient on CRPOM, although the point estimate in this case is quite large.

\footnotetext{
${ }^{15}$ Leverage subsets are formed based on lagged leverage terciles. Size subsets are formed based on each firm's lagged market capitalization rank relative to that of all NYSE firms. Small firms have market value of equity below the median of NYSE firms, medium-size firms fall in the 50-85 percentile range, and large firms have market value of equity higher than $85 \%$ of NYSE firms. Credit-rating groups are based on the firm's S\&P Issuer Credit Rating. Profitability subsets are formed based on lagged pretax earnings-to-sales terciles.
} 
TABLE 5

\section{Expected-Leverage Changes Effects by Various Firm Characteristics}

These are the results from an OLS estimation of the following model on the sample of 1,243 bonds from 1986 to 1998 :

(2)

$$
\Delta \mathrm{CS}_{i, j, t}=\beta \cdot \Delta \mathrm{LEV}_{j, t}+\gamma \cdot \Delta \mathrm{E}_{t}\left(\mathrm{LEV}_{j, t+1}\right)+\boldsymbol{\theta} \cdot \boldsymbol{\Delta} \mathbf{Z}_{\mathbf{t}}+\varepsilon_{i, j, t}
$$

Here, $\Delta \mathrm{CS}=$ change in bond credit spreads; $\Delta \mathrm{LEV}=$ change in the book leverage ratio, $\mathrm{BLEV} ; \Delta \mathrm{E}(\mathrm{LEV})$ is jointly proxied by $\Delta \mathrm{E}\left(\mathrm{BLEV}{ }^{*}\right), \Delta \mathrm{E}(\mathrm{FINDEFA})$, and $\mathrm{CRPOM} ; \Delta \mathrm{E}\left(\mathrm{BLEV}{ }^{*}\right)=$ change in target leverage ratio; target BLEV is the fitted value from a Blundell-Bond (1998) GMM estimation of equation (A-3); $\triangle E(F I N D E F A)=$ change in expected financing deficit scaled by total assets; expected FINDEFA is the fitted value from an OLS estimation of equation (A-7) (specification (1) in Table A2); CRPOM = 1 for plus/minus credit ratings, and 0 otherwise; and $\boldsymbol{\Delta} \mathbf{Z}$ includes macroeconomic control variables defined in Table 1. The coefficients on the macroeconomic control variables are not reported to save space and to focus attention on the variables of primary interest. Changes are measured over consecutive quarters. Robust standard errors are reported in parentheses. Statistical significance at the $1 \%, 5 \%$, and $10 \%$ levels is indicated by ***, ${ }^{* *}$, and ${ }^{*}$, respectively. Fis the $F$-statistic testing that the coefficients on all $3 \Delta \mathrm{E}(\mathrm{LEV})$ proxies are jointly 0 ( $\mathrm{df}=3$, [nobs - ncoeff]). Firms are divided into groups based on: i) Lagged leverage terciles: Low-leverage firms have lagged book leverage of less than 0.28 ; medium-leverage firms have lagged book leverage in the 0.28-0.38 range; and high-leverage firms have lagged book leverage higher than 0.38. ii) Lagged size: Size groups are based on market capitalization ranking in each quarter relative to the universe of NYSE firms. Small firms have market value of equity lower than that of the median NYSE firm; medium-size firms have equity values in the 50-85 percentile range; and large firms have equity values higher than $85 \%$ of NYSE firms. iii) Lagged profitability: Firms in the lowest tercile have EBIT/Sales ratio in the $-32 \%$ to $3 \%$ range; moderately profitable firms fall in the $3 \%-6 \%$ range, and the most profitable firms fall in the $6 \%-25 \%$ range. iv) Lagged S\&P Issuer Credit Ratings: investment grade (BBB- and higher) versus junk-rated issuers.

\begin{tabular}{|c|c|c|c|c|c|c|c|c|c|c|c|}
\hline & \multicolumn{3}{|c|}{ Leverage Terciles } & \multicolumn{3}{|c|}{ Size Groups } & \multicolumn{3}{|c|}{ Profitability Terciles } & \multicolumn{2}{|c|}{$\begin{array}{l}\text { Credit-Rating } \\
\text { Groups }\end{array}$} \\
\hline & Low & Medium & High & Small & Medium & Large & Low & Medium & High & Invest & Junk \\
\hline & 1 & 2 & 3 & 4 & 5 & 6 & 7 & 8 & 9 & 10 & 11 \\
\hline$\Delta \mathrm{BLEV}_{t}$ & $\begin{array}{c}0.174^{*} \\
(0.095)\end{array}$ & $\begin{array}{c}0.131 \\
(0.154)\end{array}$ & $\begin{array}{l}0.579^{\star * *} \\
(0.194)\end{array}$ & $\begin{array}{l}0.518^{\star \star} \\
(0.219)\end{array}$ & $\begin{array}{c}0.070 \\
(0.170)\end{array}$ & $\begin{array}{l}0.293^{\star \star} \\
(0.138)\end{array}$ & $\begin{array}{l}0.281 \\
(0.183)\end{array}$ & $\begin{array}{l}0.401^{\star \star \star} \\
(0.126)\end{array}$ & $\begin{array}{l}0.462^{\star * *} \\
(0.174)\end{array}$ & $\begin{array}{c}0.115 \\
(0.079)\end{array}$ & $\begin{array}{l}1.074^{* *} \\
(0.459)\end{array}$ \\
\hline$\Delta \mathrm{E}_{t}\left(\mathrm{BLEV}_{t+1}^{*}\right)$ & $\begin{array}{l}0.814^{\star \star \star} \\
(0.288)\end{array}$ & $\begin{array}{c}0.571 \\
(0.349)\end{array}$ & $\begin{array}{l}1.805^{\star \star \star} \\
(0.502)\end{array}$ & $\begin{array}{l}0.861^{\star \star} \\
(0.434)\end{array}$ & $\begin{array}{l}1.504^{\star \star \star} \\
(0.478)\end{array}$ & $\begin{array}{l}0.758^{\star \star} \\
(0.380)\end{array}$ & $\begin{array}{l}1.791^{\text {*** }} \\
(0.529)\end{array}$ & $\begin{array}{c}-0.223 \\
(0.325)\end{array}$ & $\begin{array}{l}1.054^{\star *} \\
(0.428)\end{array}$ & $\begin{array}{l}0.541^{\star \star \star} \\
(0.191)\end{array}$ & $\begin{array}{l}4.392^{\star \star \star} \\
(1.248)\end{array}$ \\
\hline$\Delta \mathrm{E}_{t}\left(\mathrm{FINDEFA}_{t+1}\right)$ & $\begin{array}{c}0.122 \\
(0.104)\end{array}$ & $\begin{array}{l}0.878^{\star \star \star} \\
(0.163)\end{array}$ & $\begin{array}{l}0.198 \\
(0.194)\end{array}$ & $\begin{array}{l}0.377^{\star \star} \\
(0.164)\end{array}$ & $\begin{array}{l}0.512^{\star *} \\
(0.207)\end{array}$ & $\begin{array}{c}0.144 \\
(0.157)\end{array}$ & $\begin{array}{l}0.494^{* *} \\
(0.213)\end{array}$ & $\begin{array}{c}0.155 \\
(0.134)\end{array}$ & $\begin{array}{c}-0.056 \\
(0.278)\end{array}$ & $\begin{array}{l}0.408^{\star \star \star} \\
(0.089)\end{array}$ & $\begin{array}{c}0.744^{*} \\
(0.415)\end{array}$ \\
\hline $\mathrm{CRPOM}_{t}$ & $\begin{array}{l}-0.012^{\star \star} \\
(0.005)\end{array}$ & $\begin{array}{l}-0.024^{\star \star \star} \\
(0.006)\end{array}$ & $\begin{array}{c}-0.012 \\
(0.009)\end{array}$ & $\begin{array}{l}-0.044^{\star \star \star} \\
(0.009)\end{array}$ & $\begin{array}{l}-0.023^{\star \star \star} \\
(0.009)\end{array}$ & $\begin{array}{c}-0.000 \\
(0.005)\end{array}$ & $\begin{array}{l}-0.037^{\star \star *} \\
(0.009)\end{array}$ & $\begin{array}{c}-0.011^{\star *} \\
(0.005)\end{array}$ & $\begin{array}{l}-0.008 \\
(0.008)\end{array}$ & $\begin{array}{l}-0.008^{\star \star} \\
(0.003)\end{array}$ & $\begin{array}{l}-0.063 \\
(0.044)\end{array}$ \\
\hline $\begin{array}{l}\text { No. of obs. } \\
\text { Adj. } R^{2} \\
\text { F }\end{array}$ & $\begin{array}{l}4,448 \\
0.09 \\
5.00^{\star \star \star}\end{array}$ & $\begin{array}{l}4,520 \\
0.15\end{array}$ & $\begin{array}{l}4,416 \\
0.12\end{array}$ & $\begin{array}{l}3,394 \\
0.11\end{array}$ & $\begin{array}{l}3,666 \\
0.13\end{array}$ & $\begin{array}{l}6,358 \\
0.08\end{array}$ & $\begin{array}{l}4,104 \\
0.14\end{array}$ & $\begin{array}{l}4,153 \\
0.11 \\
201^{*}\end{array}$ & $\begin{array}{l}4,118 \\
0.07 \\
264^{* *}\end{array}$ & $\begin{array}{c}12,233 \\
0.13\end{array}$ & $\begin{array}{l}1,185 \\
0.14 \\
5.39^{* \star *}\end{array}$ \\
\hline
\end{tabular}




\section{Robustness}

The results presented so far support our hypothesis that bond investors price their expectations of a firm's future financing choices. In this section, we investigate the robustness of our results along several dimensions: 3 alternatives to the model specification (2), different expectations for future leverage, asymmetric effects of expected-leverage increases versus decreases, and adding other firm characteristics that have been found to predict firm defaults. In all robustness tests, our proxies for future leverage continue to carry positive and significant coefficients.

\section{A. Modeling Credit-Spread Levels}

Although we present our main results using 1st-differenced regression specifications, other authors have estimated a levels model like equation (1). We present results from this specification in Table 6. In addition to the control variables $\left(\mathbf{Z}_{\mathbf{t}}\right)$ in equation (2), the regressions in Table 6 include the square of the term structure SLOPE variable and a set of bond fixed effects. We cannot include the credit-ratings-based leverage expectation CRPOM because Kisgen's (2006) logic makes predictions about leverage changes, but not about leverage levels. Still, contemporaneous leverage in Table 6 has significantly positive coefficients, as do the trade-off and pecking order proxies for expected future leverage. As in Table 4, expected future leverage has a larger effect on credit spreads than does contemporaneous leverage. We conclude that the regression specification we select does not affect our conclusions about the relevance of expected future leverage.

TABLE 6

Credit Spreads and Expected Leverage

These are the results from an OLS estimation of the following model on the sample of 1,243 bonds from 1986 to 1998 :

$$
\mathrm{CS}_{i, j, t}=\alpha+\beta \cdot \operatorname{LEV}_{j, t}+\gamma \cdot \mathrm{E}_{t}\left(\mathrm{LEV}_{j, t+1}\right)+\boldsymbol{\theta} \cdot \mathbf{Z}_{\mathbf{t}}+\omega_{i, j, t}
$$

Here, $C S=$ bond credit spreads; $L E V=$ the book leverage ratio, $B L E V ; E(L E V)$ is alternatively proxied by $E(B L E V *)$ and $\mathrm{E}(\mathrm{FINDEFA}) ; \mathrm{E}\left(\mathrm{BLEV}{ }^{*}\right)=$ target leverage ratio; target BLEV is the fitted value from a Blundell-Bond (1998) GMM estimation of equation (A-3); $E(F I N D E F A)=$ expected financing deficit scaled by total assets; expected FINDEFA is the fitted value from an OLS estimation of equation (A-7) (specification (1) in Table A2); and $\mathbf{Z}$ includes the structural-model motivated variables listed in the notes to Table 2 plus the square of the term structure SLOPE and bond fixed effects. These coefficients are not reported to save space and to focus attention on the variables of primary interest. Robust standard

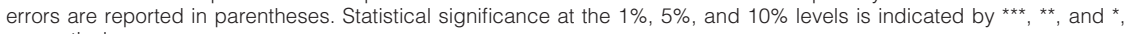
respectively.

\begin{tabular}{lcc} 
& \multicolumn{1}{c}{1} & \multicolumn{1}{c}{2} \\
\cline { 2 - 3 } BLEV $_{t}$ & $1.796^{\star \star \star}$ & $1.682^{* \star *}$ \\
$\mathrm{E}_{t}\left(\mathrm{BLEV}_{t+1}^{*}\right)$ & $(0.053)$ & $(0.054)$ \\
& & $2.074^{* \star *}$ \\
$\mathrm{E}_{t}\left(\mathrm{FINDEFA}_{t+1}\right)$ & & $(0.096)$ \\
& & \\
No. of obs. & & \\
Adj. $R^{2}$ & 14,861 & 14,575 \\
& 0.179 & 0.207
\end{tabular}

$\begin{array}{cc}3 & \frac{4}{1.766^{\star \star \star}} \\ (0.054) & 1.667^{\star \star \star} \\ & (0.054) \\ & 2.046^{\star \star \star} \\ & (0.097) \\ 0.839^{\star \star \star} & 0.445^{\star \star} \\ (0.189) & (0.188) \\ 14,861 & 14,575 \\ 0.181 & 0.207\end{array}$




\section{B. Explaining Returns Rather Than Yield Changes}

New information about leverage probably changes the price of a longerterm bond more substantially than that of a short-term bond. Our use of the simple credit-spread change ignores the bond's duration and hence might impose an unwarranted structure when we estimate our main model across bonds with various maturities. We therefore replaced the dependent variable in equation (2) with the bond's quarterly holding period return, which incorporates the effect of the bond's duration. Recall that, in discrete time, a bond's rate of return can be approximated by the (negative) product of its modified duration and its yield change: $\Delta \mathrm{P} / \mathrm{P}=-\mathrm{D}^{M} \cdot \Delta \mathrm{YTM}$, where $\mathrm{P}$ is the bond's price, $\mathrm{D}^{M}$ is its modified duration, and YTM is its yield to maturity. We focus on yield-to-maturity changes that result from changes in the credit-risk profile of the issuing firm, which allows us to rewrite equation (2) as ${ }^{16}$

$$
\mathrm{D}_{i, j, t}^{M} \cdot \Delta \mathrm{CS}_{i, j, t}=\beta \cdot \Delta \mathrm{LEV}_{j, t}+\gamma \cdot \Delta \mathrm{E}_{t}\left(\mathrm{LEV}_{j, t+1}\right)+\boldsymbol{\theta} \cdot \Delta \mathrm{Z}_{\mathbf{t}}+\varepsilon_{i, j, t}^{\mathrm{Ret}} .
$$

Expectations of future leverage under the trade-off, pecking order, and creditrating-based theories are as defined earlier. The results from estimating equation (8) (not reported) do not alter our earlier conclusions. The credit portion of a bond's holding-period return responds to expected changes in future leverage just as much as the bond's credit-spread change does. Both target leverage and expected financing deficit changes remain significant, supporting our hypothesis that leverage expectations are an important consideration in bond pricing.

\section{Nonlinear Specification}

Structural models of credit risk predict that leverage changes should affect credit spreads nonlinearly, which our main specification (2) overlooks. Modeling credit spreads as a nonlinear function of both current and future leverage transforms equation (1) into

$$
\begin{aligned}
\mathrm{CS}_{i, j, t}= & \beta \cdot \mathrm{LEV}_{j, t}+\beta^{\prime} \cdot\left[\mathrm{LEV}_{j, t}\right]^{2}+\gamma \cdot \mathrm{E}_{t}\left(\mathrm{LEV}_{j, t+1}\right) \\
& +\gamma^{\prime} \cdot\left[\mathrm{E}_{t}\left(\mathrm{LEV}_{j, t+1}\right)\right]^{2}+\boldsymbol{\theta} \cdot \mathbf{Z}_{\mathbf{t}}+\omega_{i, j, t}^{\mathrm{NL}} .
\end{aligned}
$$

Rewriting this as a difference equation yields

$$
\begin{aligned}
\Delta \mathrm{CS}_{i, j, t} & =\beta \cdot \Delta \mathrm{LEV}_{j, t}+\beta^{\prime} \cdot\left(\mathrm{LEV}_{j, t}^{2}-\mathrm{LEV}_{j, t-1}^{2}\right) \\
& +\gamma \cdot\left[\mathrm{E}_{t}\left(\mathrm{LEV}_{j, t+1}\right)-\mathrm{E}_{t-1}\left(\mathrm{LEV}_{j, t}\right)\right] \\
& +\gamma^{\prime} \cdot\left\{\left[\mathrm{E}_{t}\left(\mathrm{LEV}_{j, t+1}\right)\right]^{2}-\left[\mathrm{E}_{t-1}\left(\mathrm{LEV}_{j, t}\right)\right]^{2}\right\}+\boldsymbol{\theta} \cdot \Delta \mathrm{Z}_{\mathbf{t}}+\varepsilon_{i, j, t}^{\mathrm{NL}},
\end{aligned}
$$

where $\varepsilon_{i, j, t}^{\mathrm{NL}}=\Delta \omega_{i, j, t}^{\mathrm{NL}}$. This nonlinear specification adds the squared values of leverage, target leverage, and expected financing deficit to our base model, equation (2). The only leverage expectation proxy that we cannot effectively square is CRPOM, so we retain it in our model as is.

\footnotetext{
${ }^{16}$ This is analogous to focusing on the credit-risk component of bond returns. Note that an alternative path to equation (8) is an assumption of no change in the risk-free rate.
} 
The estimation results (not reported here) indicate that the relationship between changes in credit spreads and changes in leverage is nonlinear in the tradeoff proxy but not in the pecking order proxy. The squared target leverage term is positive and statistically significant. However, allowing for this nonlinearity does not alter our earlier conclusion(s) that expected leverage affects contemporaneous credit spreads.

\section{Alternative Targets}

Our trade-off proxy for expected leverage relies on a single set of target estimates, derived from the regressions in Table A1 in the Appendix. We also estimated models using a 1- or 3-year trailing average of past leverage to proxy for a firm's leverage target. These alternative proxies for future leverage carry even larger coefficients than those reported in Table 4, indicating that our conclusions are robust to using simpler procedures for leverage-target estimation.

\section{E. Asymmetric Response to Expected-Leverage Increases versus Decreases}

The specification in Tables 4 and 5 constrains firms to have a symmetrical response to future leverage changes, whether intending to raise or lower their leverage ratios. However, it may be systematically easier for firms to increase their debt level than to decrease it, or vice versa. If investors recognize this asymmetry in future financing behavior, then we should observe quantitatively different reactions to expected-leverage increases versus decreases. To investigate these issues, we revise our main specification (2) to permit asymmetric investor responses to anticipated leverage changes:

$$
\begin{aligned}
\Delta \mathrm{CS}_{i, j, t}= & \beta \cdot \Delta \mathrm{LEV}_{j, t}+\gamma \cdot \Delta \mathrm{E}_{t}\left(\mathrm{LEV}_{j, t+1}\right) \\
& +\gamma^{\prime} \cdot \Delta \mathrm{E}_{t}\left(\mathrm{LEV}_{j, t+1}\right) \cdot \mathrm{EXP}_{\mathrm{DEECR}}, t+1 \\
& +\gamma^{\prime \prime} \cdot \Delta \mathrm{E}_{t}\left(\mathrm{LEV}_{j, t+1}\right) \cdot \mathrm{EXP}_{\mathrm{INCR}} \mathrm{INCR}_{j+1}+\boldsymbol{\theta} \cdot \Delta \mathrm{Z}_{\mathbf{t}}+\varepsilon_{i, j, t}^{\text {Asym }},
\end{aligned}
$$

where EXP_DECR (EXP_INCR) is a dummy variable equal to 1 when the firm is expected to have lower (higher) leverage in the future. We construct measures of EXP_DECR and EXP_INCR based on each of the capital structure theories we have been considering. For the trade-off hypothesis, EXP_DECR (EXP_INCR) equals unity when a firm's $\left(\mathrm{LEV}_{j, t+1}^{*}-\mathrm{LEV}_{j, t}\right)$ is in the bottom (top) tercile for a given quarter. For the pecking order hypothesis, EXP_DECR (EXP_INCR) equals unity when a firm's $\mathrm{E}_{t}\left(\mathrm{FINDEFA}_{j, t+1}\right)$ is in the bottom (top) tercile for a given quarter.

In an estimation of equation (11) (results not tabulated), the coefficients on the trade-off proxies weakly suggest $(p=0.098)$ that firms above their targets are expected to adjust more slowly than firms below their targets. The estimated coefficients on the pecking order proxies indicate statistically and economically similar $(p=0.505)$ effects of expected future leverage on credit spreads. For either sort of asymmetry, the coefficients on current leverage $\left(\Delta \mathrm{LEV}_{t}\right)$ remain very close to those reported in Table 4 . We conclude that our findings are not systematically different for firms expected to increase versus decrease their leverage. 


\section{F. Adding Accounting Measures as Explanatory Variables}

Previous research shows that accounting variables forecast a firm's default probability (see Altman (1968), Ohlson (1980), Zmijewski (1984), Shumway (2001), Hillegeist, Keating, Cram, and Lundsted (2004), Beaver, McNichols, and Rhie (2005), and Das, Hanouna, and Sarin (2009)), but the exact nexus remains unknown. Our study raises the possibility that accounting variables may forecast default because they proxy for expected future financing decisions. To investigate whether this conjecture has any empirical validity, we replace expected future leverage in equation (5) with a set of accounting variables $\left(\mathrm{A}_{j, t}\right)$ to get

$$
\Delta \mathrm{CS}_{i, j, t}=\beta \cdot \Delta \mathrm{LEV}_{j, t}+\boldsymbol{\tau} \cdot \Delta \mathbf{A}_{\mathbf{j}, \mathbf{t}}+\boldsymbol{\theta} \cdot \Delta \mathbf{Z}_{\mathbf{t}}+\varepsilon_{i, j, t}^{\text {Acct }} .
$$

The vector $\mathbf{A}_{\mathbf{j}, \mathbf{t}}$ includes various combinations of variables that have been used as default predictors by previous researchers:

O-SCORE $=$ a default probability score based on Ohlson (1980),

Z-SCORE $=$ a default probability score based on Altman (1968),

NI_GROWTH $=$ change in net income scaled by total assets,

$\mathrm{IC}=$ interest coverage ratio,

$\mathrm{QR}=$ quick ratio,

$\mathrm{CASH}=$ cash availability,

TRADE $=$ trading account activities (inventories / cost of goods sold),

SL_GROWTH $=$ change in sales scaled by lagged sales.

After estimating equation (12), we investigate the effect of adding future leverage changes to the set of explanatory variables.

Regardless of the combination of accounting variables used, our future leverage proxies are always strongly significant (results not tabulated). Furthermore, adding future leverage proxies to equation (12) reduces the size and often the statistical significance of the accounting predictors of default. This is consistent with the possibility that these variables predict default probability in part because they predict subsequent leverage changes.

\section{Conclusion}

In this paper, we demonstrate that credit spreads reflect future changes in a firm's actual leverage, consistent with the theoretical work of CG (2001). The effect of future leverage is large, generally exceeding the effect of contemporaneous leverage. This relation naturally raises the question of how investors form expectations about a firm's future leverage. To investigate, we construct 3 proxies for leverage changes, based on 3 theoretical perspectives on firm capital structure. One proxy relies on the trade-off theory, another relies on the pecking order theory, and the 3rd derives from Kisgen's (2006) hypothesis that firms enjoy discrete benefits from moving to a higher (letter) credit rating. We use all 3 proxies for investors' leverage expectations to explain credit-spread changes in a sample of 1,243 bonds over the period 1986-1998.

Our analysis contributes 3 important empirical findings. First, we show that bondholders predict future leverage changes resulting from changes in outstanding debt and equity, but not from fluctuations in stock or bond prices. This negative 
conclusion about future price changes encourages us to believe that credit spreads actually reflect anticipated changes in leverage. Although credit spreads could be either positively or negatively related to future leverage, our results indicate a strong positive relation. That is, high contemporaneous credit spreads seem to reflect expected increases in future leverage. The alternative possibility (that unusually high spreads cause lower leverage by discouraging borrowing) is inconsistent with the data.

Second, we confirm that investors' expectations about future leverage changes significantly affect credit spreads and that this effect is above and beyond (and often larger than) the effect of contemporaneous leverage changes. Since most previous studies on the determinants of credit spreads and credit-spread changes have focused on a firm's current financial state (e.g., Collin-Dufresne et al. (2001), Krishnan et al. (2005), Avramov et al. (2007), Campbell and Taksler (2003), and Chen et al. (2007)), our analysis adds to the literature about the factors affecting bond prices.

Finally, our analysis provides some evidence on the extent to which investors act in accordance with the various theories of capital structure. In the overall sample, the trade-off, pecking order, and credit-rating theories all yield significant proxies for expected future leverage. Bond investors find these 3 indicators to be complementary and use all of them when forming expectations about the average firm's future leverage. However, estimating our model for firm subgroups (based on leverage, size, profitability, and credit rating) indicates that the trade-off proxy for future leverage is more robust than the other two. While all 3 theories of capital structure receive some empirical support, the trade-off theory seems the most broadly applicable.

\section{Appendix. Proxies for Expected Future Leverage}

Our analysis requires proxies for investors' expectations of future leverage. We rely on 3 such proxies, based on i) the trade-off and ii) pecking order theories of capital structure and iii) Kisgen's (2006) hypothesis that firms prefer higher debt ratings rather than a specific leverage ratio. These determinants of future leverage are not mutually exclusive.

\section{The Trade-Off Hypothesis}

The trade-off theory of capital structure maintains that firms select a valuemaximizing leverage ratio by trading off the costs and benefits of debt. Firms move toward this optimal leverage target gradually, perhaps reflecting positive adjustment costs (Fischer, Heinkel, and Zechner (1989), Leary and Roberts (2005)):

$$
\mathrm{LEV}_{j, t+1}-\mathrm{LEV}_{j, t}=\lambda\left(\mathrm{LEV}_{j, t+1}^{*}-\mathrm{LEV}_{j, t}\right)+\tilde{\delta}_{j, t+1},
$$

where

$\mathrm{LEV}_{j, t}$ is the $j$ th firm's observed leverage at the end of quarter $t$,

$\mathrm{LEV}_{j, t+1}^{*}$ is the $j$ th firm's target leverage for the end of quarter $t+1$, and

$\lambda$ is the quarterly adjustment speed.

Equation (A-1) thus implies that investors should expect higher (lower) future leverage when the firm's leverage is below (above) its target. 
Previous researchers have estimated models that permit target leverage to vary across firms and over time:

$$
\mathrm{LEV}_{j, t+1}^{*}=\boldsymbol{\beta} \mathbf{X}_{\mathbf{j}, \mathbf{t}},
$$

where $\mathbf{X}_{\mathbf{j}, \mathbf{t}}$ is a vector of the $j$ th firm's characteristics designed to capture the costs and benefits of debt. We use the following such characteristics:

EBIT_TA = earnings before interest and taxes as a proportion of total assets,

$\mathrm{MB}=$ the ratio of assets' market-to-book values,

DEP_TA $=$ depreciation expense as a proportion of total assets,

$\operatorname{lnTA}=\log$ of total book assets (a measure of firm size),

FA_TA $=$ fixed assets as a proportion of total assets,

R\&D_DUM $=$ a dummy variable equal to 1 if research and development (R\&D) expenditures are not reported, and 0 otherwise,

R\&D_TA $=$ research and development expenses as a proportion of total assets,

RATED $=$ a dummy variable equal to 1 if the firm has a debt rating, and 0 otherwise,

IND_MED = the prior quarter's median leverage ratio for the firm's industry, where industry classifications are based on the 48 industry categories in Fama and French (1997), and

Firm fixed effects (Flannery and Rangan (2006), Lemmon, Roberts, and Zender (2008)).

Panel C of Table 1 provides summary statistics for these variables.

Substituting equation (A-2) into equation (A-1) produces the estimable model

$$
\mathrm{LEV}_{j, t+1}=\lambda\left(\boldsymbol{\beta} \mathbf{X}_{\mathbf{j}, \mathbf{t}}\right)+(1-\lambda) \mathrm{LEV}_{j, t}+\tilde{\delta}_{j, t+1}
$$

We estimate equation (A-3) via Blundell and Bond's (1998) GMM system using 19732006 data for our sample firms. The results are presented in column 1 of Table A1. The model fits the data well, and the estimated quarterly adjustment speed (8.2\%) implies an average annual adjustment speed $(29 \%)$ close to other estimates in the literature (Leary and Roberts (2005), Flannery and Rangan (2006), Faulkender, Flannery, Hankins, and Smith (2012), and Lemmon et al. (2008)). Explanatory variables carry appropriate signs, comparable with those reported in previous studies. ${ }^{17}$ The results reported in Tables 4-6 treat the fitted values from this Blundell-Bond (1998) estimation as our 1st proxy for expected future leverage. ${ }^{18}$ We check robustness by estimating a target from each of the 2 alternative specifications of equation (A-3). Column 2 of Table A1 includes firm fixed effects and constrains $\lambda=1$, while column 3 ignores the data's panel nature and reports OLS estimates. The main conclusions are robust to using any of these 3 target estimates.

We first test whether these leverage targets capture investors' expectations in a meaningful way. Every quarter we calculate each firm's distance from its target leverage as $\left[\mathrm{E}_{t}\left(\mathrm{LEV}_{t+1}^{*}\right)-\mathrm{LEV}_{t}\right]$ and classify it as below target (if the distance is positive) or above target (if the distance is negative). If our targets are indeed meaningful, we should observe that below-target firms increase their leverage in the future and above-target firms decrease it. Consistent with this conjecture, mean leverage change is significantly negative

\footnotetext{
${ }^{17}$ Estimating equation (A-3) for a market-valued leverage definition yields similar results to the ones shown in Table A1.

${ }^{18}$ In an attempt to remove seasonal variation from our leverage estimates, we include quarterly dummy variables when estimating equation (A-3) and then omit the quarterly effects when computing target leverage ratios. This adjustment has virtually no effect on the estimates or tests reported in the paper.
} 
TABLE A1

Estimation of Target Leverage

This is an estimation of the following model on the quarterly accounting data for the 394 bond issuers in our sample from 1973 to 2006:

$$
\operatorname{LEV}_{j, t+1}=\lambda\left(\boldsymbol{\beta} \mathbf{X}_{\mathbf{j}, \mathbf{t}}\right)+(1-\lambda) \mathrm{LEV}_{j, t}+\tilde{\delta}_{j, t+1}
$$

LEV is a leverage ratio, $\mathbf{X}$ is a vector of firm characteristics, which includes the following variables: EBIT_TA is earnings before interest and taxes scaled by total assets, MB is the ratio of market-to-book value of assets, DEP_TA is depreciation expense to total assets, InTA is the natural log of total assets, FA_TA is the ratio of fixed-to-total assets, R\&D_DUM is an indicator variable for whether the firm reports an R\&D expenditure or not, R\&D_TA is R\&D expenditures scaled by total assets, RATED is an indicator for whether the firm has rated debt, and IND_MED is the median leverage for each firm's industry. Column 1 is a Blundell-Bond (1998) GMM estimation of the model. Column 2 is a panel estimation under the assumption of full adjustment toward the target every period (i.e., $\lambda=1$ ). Column 3 is an OLS estimation under the partialadjustment assumption. Robust standard errors are reported in parentheses. Statistical significance at the $1 \%, 5 \%$, and $10 \%$ levels is indicated by ${ }^{\star \star *},{ }^{\star *}$, and ${ }^{*}$, respectively.

\begin{tabular}{|c|c|c|c|}
\hline & GMM & $\mathrm{FE} \lambda=1$ & OLS \\
\hline & 1 & 2 & 3 \\
\hline $\mathrm{LEV}_{t}$ & $\begin{array}{l}0.918^{\star \star \star} \\
(0.003)\end{array}$ & & $\begin{array}{l}0.962^{\star \star \star} \\
(0.003)\end{array}$ \\
\hline EBIT_TA $t$ & $\begin{array}{l}-0.093^{\text {** }} \\
(0.014)\end{array}$ & $\begin{array}{l}-0.803^{\star \star \star} \\
(0.032)\end{array}$ & $\begin{array}{l}-0.073^{\star \star \star} \\
(0.017)\end{array}$ \\
\hline $\mathrm{MB}_{t}$ & $\begin{array}{l}0.001^{\star \star} \\
(0.001)\end{array}$ & $\begin{array}{l}-0.009^{\star \star \star} \\
(0.001)\end{array}$ & $\begin{array}{l}0.001^{\star \star \star} \\
(0.000)\end{array}$ \\
\hline DEP_TA $t$ & $\begin{array}{l}-0.027 \\
(0.056)\end{array}$ & $\begin{array}{l}-0.373^{\star \star \star} \\
(0.128)\end{array}$ & $\begin{array}{c}0.039 \\
(0.044)\end{array}$ \\
\hline $\ln T A_{t}$ & $\begin{array}{l}-0.001^{\star \star \star} \\
(0.000)\end{array}$ & $\begin{array}{l}0.002^{\star \star} \\
(0.001)\end{array}$ & $\begin{array}{l}-0.001^{\text {*ᄎ*}} \\
(0.000)\end{array}$ \\
\hline $\mathrm{FA}_{-} \mathrm{TA}_{t}$ & $\begin{array}{l}0.016^{\star \star \star} \\
(0.003)\end{array}$ & $\begin{array}{l}0.056^{\star \star \star} \\
(0.008)\end{array}$ & $\begin{array}{l}0.004^{\star \star \star} \\
(0.002)\end{array}$ \\
\hline R\&D_DUMt & $\begin{array}{c}0.001 \\
(0.001)\end{array}$ & $\begin{array}{l}0.006^{\star \star \star} \\
(0.002)\end{array}$ & $\begin{array}{l}0.002^{\star \star \star} \\
(0.001)\end{array}$ \\
\hline$R \& D_{-} T A_{t}$ & $\begin{array}{c}0.045 \\
(0.078)\end{array}$ & $\begin{array}{l}-0.963^{\star \star \star} \\
(0.178)\end{array}$ & $\begin{array}{l}-0.122^{\star \star} \\
(0.048)\end{array}$ \\
\hline RATED $_{t}$ & $\begin{array}{l}0.006^{\star \star \star} \\
(0.001)\end{array}$ & $\begin{array}{l}0.046^{\star \star \star} \\
(0.002)\end{array}$ & $\begin{array}{l}0.003^{\star \star \star} \\
(0.001)\end{array}$ \\
\hline IND_MED $_{t}$ & $\begin{array}{c}-0.004 \\
(0.005)\end{array}$ & $\begin{array}{l}0.438^{\star \star \star} \\
(0.010)\end{array}$ & $\begin{array}{c}0.005 \\
(0.004)\end{array}$ \\
\hline Intercept & $\begin{array}{l}0.039^{\star * *} \\
(0.011)\end{array}$ & $\begin{array}{l}0.104^{\star \star \star} \\
(0.024)\end{array}$ & $\begin{array}{l}0.020^{\star \star \star} \\
(0.005)\end{array}$ \\
\hline $\begin{array}{l}\text { Quarter dummies } \\
\text { Firm fixed effects }\end{array}$ & $\begin{array}{l}\text { Yes } \\
\text { Yes }\end{array}$ & $\begin{array}{l}\text { Yes } \\
\text { Yes }\end{array}$ & $\begin{array}{l}\text { Yes } \\
\text { No }\end{array}$ \\
\hline $\begin{array}{l}\text { No. of obs. } \\
\text { Adj. } R^{2}\end{array}$ & $\begin{array}{c}32,962 \\
0.93\end{array}$ & $\begin{array}{c}33,259 \\
0.23\end{array}$ & $\begin{array}{c}32,962 \\
0.93\end{array}$ \\
\hline
\end{tabular}

(positive) up to 4 quarters into the future for firms currently above (below) their leverage target (results not tabulated).

\section{The Pecking Order Hypothesis}

The pecking order theory of capital structure is based on the presumption that transaction costs (in particular, the asymmetric information component of those costs) are higher for equity issuances than bond issuances. Thus, firms tend to issue debt (rather than equity) when they need to raise external funds. Conversely, firms with excess internally generated funds tend to retire debt in order to preserve their options to borrow again (Lemmon and Zender (2010)). Therefore, an anticipated financing deficit (surplus) should be associated with higher (lower) future leverage (Shyam-Sunder and Myers (1999), Lemmon and Zender (2010)). Following Shyam-Sunder and Myers, we define a firm's net need to raise external funds as its "financing deficit":

$$
\operatorname{FINDEFA}_{j, t}=\left(\mathrm{DIV}_{j, t}+\mathrm{I}_{j, t}+\Delta \mathrm{W}_{j, t}-\mathrm{C}_{j, t}\right) / \operatorname{Assets}_{j, t},
$$


where

$\mathrm{DIV}_{j, t}$ is the $j$ th firm's cash dividends paid during the quarter ending at $t$, $\mathrm{I}_{j, t}$ is the $j$ th firm's net investments during the quarter ending at $t$,

$\Delta \mathrm{W}_{j, t}$ is the $j$ th firm's change in working capital during the quarter ending at $t$,

$\mathrm{C}_{j, t}$ is the $j$ th firm's net cash flow after interest and taxes during quarter $t$, and

Assets $_{j, t}$ is the book value of the $j$ th firm's assets at the end of quarter $t .^{19}$

Shyam-Sunder and Myers specify that the pecking order hypothesis should result in leverage changes following the pattern ${ }^{20}$

$$
\mathrm{LEV}_{j, t+1}-\mathrm{LEV}_{j, t}=\mathrm{FINDEFA}_{j, t+1}+\delta_{j, t+1} .
$$

Under the pecking order theory, expected future leverage follows from a simple rearrangement of equation (A-5):

$$
\mathrm{E}_{t}\left(\mathrm{LEV}_{j, t+1}\right)=\mathrm{E}_{t}\left(\mathrm{FINDEFA}_{j, t+1}\right)+\mathrm{LEV}_{j, t} .
$$

Unlike the trade-off hypothesis, the prior literature provides little guidance about predicting FINDEFA. We therefore specify a parsimonious model of the form

$$
\text { FINDEFA }_{j, t+1}=\phi \mathbf{Y}_{\mathbf{j}, \mathbf{t}}+v_{j, t+1}
$$

where $\mathbf{Y}_{\mathbf{j}, \mathbf{t}}$ is a vector of firm $j$ 's characteristics at the end of quarter $t$. We experiment with various such characteristics but ultimately limit the set to those that appear statistically most important:

FINDEFA $_{j, t-k+1},(k=1$ to 4$)=$ up to 4 lags of the dependent variable defined previously,

IND_DUM $_{j, t}=$ an industry dummy based on the 48 industries defined in Fama and French (1997), and

EBIT_TA $_{j, t}=$ earnings before interest and taxes as a proportion of total assets.

Columns 1 and 2 of Table A2 indicate that the 1st lag of FINDEFA has the strongest explanatory power in equation (A-7), and that adding further lags or other accounting variables does not improve the model's fit from an adjusted $R^{2}=0.38$ (we report only a subset of all our estimation results).

We experiment with alternative estimation techniques as well. Column 3 of Table A2 incorporates the data's panel characteristics by adding firm fixed effects to control for unobserved variables that are relatively stable over time for each firm. However, the dynamic panel specification in column 3 might provide biased coefficient estimates on the lagged dependent variable. We reestimate this regression, substituting an instrumental variable for FINDEFA $t_{t-1}$, and then we report the results in column 4 of Table A2. This correction does not materially affect the model's fit or estimated coefficients. Therefore, we use fitted values from the specification in column 1 as our pecking-order-based proxy for expected future leverage. ${ }^{21}$

\footnotetext{
${ }^{19}$ Investment $\left(\mathrm{I}_{j, t}\right)$ is defined by the following Compustat Quarterly data items: $[91-85-109+$ $90-83+94-110]$ for format code 7 , and $[91-85+90-83+94+95]$ for format codes $1-3$. Change in working capital $\left(\Delta \mathrm{W}_{j, t}\right)$ is defined by the following Compustat Quarterly data items: [74$103-104-105-106-107-75-112]$ for format code $7,[74+75+73]$ for format code 1 , and $[74-75-73]$ for format codes 2 and 3 . Net cash flow after interest and taxes $\left(C_{j, t}\right)$ is defined by the following Compustat Quarterly data items: $[76+77+78+79+80+102+81+114]$ for format code 7 and $[76+77+78+79+80+102+81+87]$ for format codes $1-3$.

${ }^{20}$ Shyam-Sunder and Myers (1999) find support for this version of the pecking order hypothesis, although Fama and French (2002) and Frank and Goyal (2003) do not.

${ }^{21}$ We adjust our estimates of expected financing deficit for seasonality in the same manner in which we adjust our leverage targets. We start by estimating equation (A-7) with quarterly dummy variables and then calculate fitted values, excluding the dummy variables.
} 
TABLE A2

Estimation of Expected Financing Deficit

This is an estimation of the following model on the quarterly accounting data for the 394 bond issuers in our sample from 1973 to 2006 :

$$
\text { FINDEFA }_{j, t+1}=\phi \mathbf{Y}_{\mathbf{j}, \mathbf{t}}+v_{j, t+1}
$$

FINDEFA is a measure of financing deficit scaled by total assets; $\mathbf{Y}$ is a vector of firm characteristics, which includes the following variables in addition to lags of FINDEFA: EBIT_TA is EBIT as a proportion of total assets and industry dummies based on the Fama-French (1997) 48 industry categorizations. Columns 1 and 2 of Table A2 are OLS estimations of the model. Column 3 is a panel estimation that includes firm fixed effects. Column 4 is a dynamic panel estimation with firm fixed effects where the 2nd lag of FINDEFA is used as an instrument for the 1st lag. Robust standard errors are reported in parentheses. Statistical significance at the $1 \%, 5 \%$, and $10 \%$ levels is indicated by ***, ${ }^{* *}$, and * , respectively.

\begin{tabular}{|c|c|c|c|c|}
\hline & OLS & OLS & Panel & IV \\
\hline & 1 & 2 & 3 & 4 \\
\hline FINDEFA $_{t}$ & $\begin{array}{l}0.594^{\star \star *} \\
(0.012)\end{array}$ & $\begin{array}{l}0.602^{\star \star \star} \\
(0.009)\end{array}$ & $\begin{array}{l}0.556^{\star \star \star} \\
(0.010)\end{array}$ & $\begin{array}{l}0.510^{* * *} \\
(0.009)\end{array}$ \\
\hline FINDEFA $_{t-1}$ & $\begin{array}{c}-0.018 \\
(0.011)\end{array}$ & & & \\
\hline FINDEFA $_{t-2}$ & $\begin{array}{l}-0.032^{\star \star \star} \\
(0.010)\end{array}$ & & & \\
\hline FINDEFA $_{t-3}$ & $\begin{array}{l}0.098^{\star \star *} \\
(0.009)\end{array}$ & & & \\
\hline EBIT_TA $t$ & $\begin{array}{r}-0.032^{*} \\
(0.018)\end{array}$ & $\begin{array}{c}-0.025 \\
(0.018)\end{array}$ & $\begin{array}{c}0.023 \\
(0.021)\end{array}$ & $\begin{array}{c}0.010 \\
(0.017)\end{array}$ \\
\hline Intercept & $\begin{array}{c}0.005 \\
(0.008)\end{array}$ & $\begin{array}{c}0.004 \\
(0.008)\end{array}$ & $\begin{array}{c}0.005 \\
(0.011)\end{array}$ & $\begin{array}{c}0.002 \\
(0.011)\end{array}$ \\
\hline $\begin{array}{l}\text { Industry dummies } \\
\text { Quarter dummies } \\
\text { Firm fixed effects }\end{array}$ & $\begin{array}{l}\text { Yes } \\
\text { Yes } \\
\text { No }\end{array}$ & $\begin{array}{l}\text { Yes } \\
\text { Yes } \\
\text { No }\end{array}$ & $\begin{array}{l}\text { Yes } \\
\text { Yes } \\
\text { Yes }\end{array}$ & $\begin{array}{l}\text { Yes } \\
\text { Yes } \\
\text { Yes }\end{array}$ \\
\hline $\begin{array}{l}\text { No. of obs. } \\
\text { Adj. } R^{2}\end{array}$ & $\begin{array}{c}25,069 \\
0.38\end{array}$ & $\begin{array}{c}26,426 \\
0.38\end{array}$ & $\begin{array}{c}26,426 \\
0.32\end{array}$ & $\begin{array}{c}25,968 \\
0.38\end{array}$ \\
\hline
\end{tabular}

As with the leverage targets, we examine whether our expected FINDEFA values capture investors' expectations of future leverage changes. In every quarter during the sample period we use the fitted value from equation (A-7) to separate firms into those expected to run a financing deficit and those expected to run a surplus. The mean future leverage change is negative for all firms up to 4 quarters into the future. This probably reflects positive retained earnings. However, the subsequent leverage increases significantly over the next 4 quarters for firms with negative predicted FINDEFA, which the pecking order would predict to be financing themselves with debt $(\mathrm{pr}=0.10$ for tests of mean differences and $\mathrm{pr}=0.05$ for tests of median differences, not tabulated).

\section{The Credit-Rating-Based Hypothesis}

Kisgen (2006) hypothesizes that credit ratings affect firms' leverage decisions, perhaps in addition to either trade-off or pecking order considerations. He argues that there are distinct advantages to a higher letter grade. Consequently, firms close to the next higher rating (e.g., $\mathrm{BBB}+$ is close to $\mathrm{A}-$ ) prefer to avoid issuing new debt. Firms close to a lower rating (e.g., A-relative to $\mathrm{A}$ ) also avoid debt issuance to preserve their current letter grade. Kisgen confirms that firms with a "plus or minus" credit rating $(\mathrm{CRPOM}=1)$ more frequently choose equity over debt financing, ceteris paribus.

Given the simplicity of capturing this insight, we include CRPOM as one of our proxies for expected changes in future leverage. Our findings are generally consistent with those in Kisgen (2006). All firms with a credit rating manifest a decline in leverage over the subsequent 4 quarters, but firms with $\mathrm{CRPOM}=1$ have a significantly larger $(\mathrm{pr}=0.1)$ leverage decline. We conclude that a firm's proximity to a letter-rating change constitutes a meaningful proxy for leverage expectations. 


\section{References}

Altman, E. I. "Financial Ratios, Discriminant Analysis and the Prediction of Corporate Bankruptcy." Journal of Finance, 23 (1968), 589-609.

Avramov, D.; G. Jostova; and A. Philipov. "Understanding Changes in Corporate Credit Spreads." Financial Analysts Journal, 63 (2007), 90-105.

Beaver, W.; M. McNichols; and J.-W. Rhie. "Have Financial Statements Become Less Informative? Evidence from the Ability of Financial Ratios to Predict Bankruptcy." Review of Accounting Studies, 10 (2005), 93-122.

Bharath, S. T., and T. Shumway. "Forecasting Default with the Merton Distance to Default Model." Review of Financial Studies, 21 (2008), 1339-1369.

Black, F., and M. Scholes. "The Pricing of Options and Corporate Liabilities." Journal of Political Economy, 81 (1973), 637-654.

Blundell, R., and S. Bond. "Initial Conditions and Moment Restrictions in Dynamic Panel Data Models." Journal of Econometrics, 87 (1998), 115-143.

Campbell, J. Y., and G. B. Taksler. "Equity Volatility and Corporate Bond Yields." Journal of Finance, 58 (2003), 2321-2349.

Chen, L.; D. A. Lesmond; and J. Wei. "Corporate Yield Spreads and Bond Liquidity." Journal of Finance, 62 (2007), 119-149.

Collin-Dufresne, P., and R. S. Goldstein. "Do Credit Spreads Reflect Stationary Leverage Ratios?" Journal of Finance, 56 (2001), 1929-1957.

Collin-Dufresne, P.; R. S. Goldstein; and J. S. Martin. "The Determinants of Credit-Spread Changes." Journal of Finance, 56 (2001), 2177-2207.

Das, S. R.; P. Hanouna; and A. Sarin. "Accounting-Based versus Market-Based Cross-Sectional Models of CDS Spreads.” Journal of Banking and Finance, 33 (2009), 719-730.

Dastidar, S. "Does Asset Supply Affect Asset Prices? Evidence from the Agency Bond Market." Working Paper, Columbia University (2008).

Duffie, D.; L. Saita; and K. Wang. "Multi-Period Corporate Default Prediction with Stochastic Covariates." Journal of Financial Economics, 83 (2007), 635-665.

Elton, E. J.; M. J. Gruber; D. Agrawal; and C. Mann. "Explaining the Rate Spread on Corporate Bonds.” Journal of Finance, 56 (2001), 247-277.

Eom, Y. H.; J. Helwege; and J.-Z. Huang. "Structural Models of Corporate Bond Pricing: An Empirical Analysis." Review of Financial Studies, 17 (2004), 499-544.

Fama, E. F., and K. R. French. "Industry Costs of Equity." Journal of Financial Economics, 43 (1997), 153-193.

Fama, E. F., and K. R. French. "Testing Tradeoff and Pecking Order Predictions about Dividends and Debt." Review of Financial Studies, 15 (2002), 1-33.

Faulkender, M.; M. J. Flannery; K. W. Hankins; and J. M. Smith. "Cash Flows and Leverage Adjustments." Journal of Financial Economics, 103 (2012), 632-646.

Fischer, E. O.; R. Heinkel; and J. Zechner. "Dynamic Capital Structure Choice: Theory and Tests." Journal of Finance, 44 (1989), 19-40.

Flannery, M. J., and K. P. Rangan. "Partial Adjustment Toward Target Capital Structures." Journal of Financial Economics, 79 (2006), 469-506.

Frank, M. Z., and V. K. Goyal. "Testing the Pecking Order Theory of Capital Structure.” Journal of Financial Economics, 67 (2003), 217-248.

Hillegeist, S. A.; E. K. Keating; D. P. Cram; and K. G. Lundsted. "Assessing the Probability of Bankruptcy." Review of Accounting Studies, 9 (2004), 5-34.

Hui, C. H.; C. F. Lo; and M. X. Huang. "Are Corporates' Target Leverage Ratios Time-Dependent?" International Review of Financial Analysis, 15 (2006), 220-236.

Kisgen, D. J. “Credit Ratings and Capital Structure.” Journal of Finance, 61 (2006), 1035-1072.

Krishnan, C. N. V.; P. H. Ritchken; and J. B. Thomson. "Monitoring and Controlling Bank Risk: Does Risky Debt Help?” Journal of Finance, 60 (2005), 343-378.

Leary, M. T., and M. R. Roberts. "Do Firms Rebalance Their Capital Structure?" Journal of Finance, 60 (2005), 2575-2619.

Lemmon, M. L.; M. R. Roberts; and J. F. Zender. "Back to the Beginning: Persistence and the CrossSection of Corporate Capital Structure.” Journal of Finance, 63 (2008), 1575-1608.

Lemmon, M. L., and J. F. Zender. "Debt Capacity and Tests of Capital Structure Theories." Journal of Financial and Quantitative Analysis, 45 (2010), 1161-1187.

Longstaff, F. A.; S. Mithal; and E. Neis. "Corporate Yield Spreads: Default Risk or Liquidity? New Evidence from the Credit Default Swap Market.” Journal of Finance, 60 (2005), 2213-2253.

Merton, R. C. "On the Pricing of Corporate Debt: The Risk Structure of Interest Rates." Journal of Finance, 29 (1974), 449-470. 
Newman, Y., and A. Rierson. "Illiquidity Spillovers: Theory and Evidence from European Telecom Bond Issuance.” Working Paper, Stanford University (2004).

Ohlson, J. A. "Financial Ratios and the Probabilistic Prediction of Bankruptcy." Journal of Accounting Research, 18 (1980), 109-131.

Sarig, O., and A. Warga. "Bond Price Data and Bond Market Liquidity." Journal of Financial and Quantitative Analysis, 24 (1989), 367-378.

Shumway, T. "Forecasting Bankruptcy More Accurately: A Simple Hazard Model." Journal of Business, 74 (2001), 101-124.

Shyam-Sunder, L., and S. C. Myers. "Testing Static Tradeoff against Pecking Order Models of Capital Structure." Journal of Financial Economics, 51 (1999), 219-244.

Sweeney, R. J.; A. D. Warga; and D. Winters. "The Market Value of Debt, Market versus Book Value of Debt, and Returns on Assets.” Financial Management, 26 (1997), 5-21.

Warga, A. D. "Corporate Bond Price Discrepancies in the Dealer and Exchange Markets." Journal of Fixed Income, 1 (1991), 7-16.

Zmijewski, M. E. "Methodological Issues Related to the Estimation of Financial Distress Prediction Models.” Journal of Accounting Research, 22 (1984), 59-82. 